\title{
Selling Mayberry: Communities and Individuals in Law and Economics
}

\author{
Gideon Parchomovsky† \& Peter Siegelman $\ddagger$
}

\section{TABLE OF CONTENTS}

Introduction

I. The Story of Cheshire

A. The Gavin Plant's Pollution....................................................... 86

B. A Buyout Emerges from the Smoke ........................................... 89

II. The Economic Theory of Nuisance Law .......................................... 92

III. Background Legal Rules and Their Application to Cheshire .............. 98

A. Ohio Nuisance Law ................................................................ 99

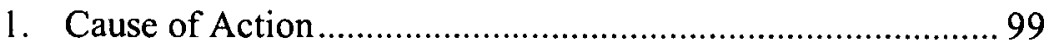

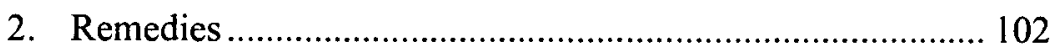

B. Expected Rational Behavior Under Traditional Economic

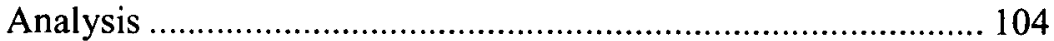

1. The Pollution Holdout........................................................ 104

2. The Expansion Holdout.............................................................. 107

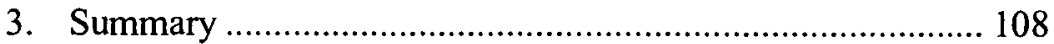

IV. Explaining the Absence of Holdouts................................................ 108

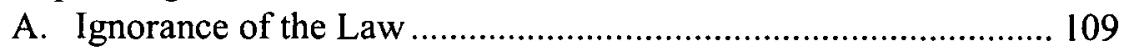

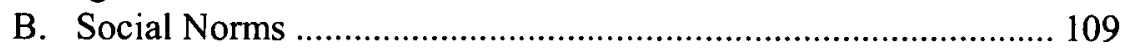

C. The Realities of Nuisance ...................................................... 110

1. Living Near a Polluter ....................................................... 110

2. Reputational Stakes ......................................................... 112

Copyright (C) 2004 Califomia Law Review, lnc. Califomia Law Review, lnc. (CLR) is a Califomia nonprofit corporation. CLR and the authors are solely responsible for the content of their publications.

$\dagger$ Assistant Professor, University of Pennsylvania School of Law.

$\$$ Associate Professor, Fordham University School of Law. This Article greatly benefited from comments and criticisms by lan Ayres, Tom Baker, Robert Cooter, Hanoch Dagan, Kirsten Edwards, Jill Fisch, William Fischel, Jim Fleming, Jon Goldberg, Alon Harel, Geoffrey Hazard, Michael Heller, Nick Johnson, Jason Johnston, Seth Kreimer, Douglas Laycock, Doug Lichtman, Michael Pereira, Wendell Pritchett, Katharine Q. Seelye, Alex Stein, Steve Thel, lan Weinstein, and Ben Zipursky. Special thanks to Abraham Bell and Bob Ellickson for insightful suggestions. For excellent research assistance we thank Anna Benestate, Jon Morales, and especially Guy McPherson at Fordham, along with David Goldman, Brian Lenhard, and especially Bill Draper at Penn. We are deeply grateful to all the Cheshire residents who agreed to speak with us and to various staff members of the Columbus Dispatch who contributed to our understanding of the story. 
D. Community Externalities .......................................................... 113

1. Fixed Costs, Availability, and Community Size ................... 115

2. Friendships and Community Networks ................................. 116

3. Community Externalities and Individual Decision Making .....

V. Implications for Tort Theory ......................................................... 124

VI. Implications for Collective Bargaining Theory.............................. 130

VII.Implications for Takings Policy ................................................. 133

A. A New Takings Taxonomy ……………….............................. 134

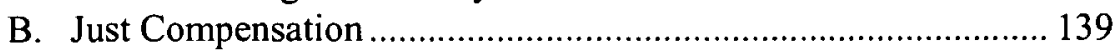

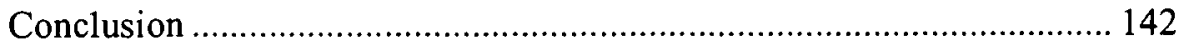

Appendix: One Year Later.................................................................. 145 


\title{
Selling Mayberry: Communities and Individuals in Law and Economics
}

\author{
Gideon Parchomovsky \& Peter Siegelman
}

In an unusual turn of events, American Electric Power Company recently acquired the entire small town of Cheshire, Ohio. The buyout was intended to put an end to a serious pollution problem caused by the company's giant power plant, which was located at the edge of town. Although the plant was worth substantially more than the town, no simple Coasean bargain guided the buyout. This Article combines ethnographic research into the Cheshire buyout with theoretical insights from law and economics to present an empirical and theoretic challenge to the standard account of nuisance disputes. It explores the transaction in detail and explains what prevented the collective action and holdout problems usually thought to hinder bargaining with groups. Specifically, this Article shows how incorporating the role of community into conventional theory offers a new understanding of the likelihood of holdouts, the importance of community dynamics, and the interdependency inherent in community-wide nuisance actions. Finally, this Article briefly explores the implications of this new understanding for tort law, collective action, and the law of takings.

\section{INTRODUCTION}

"We used to be like Mayberry."

"A little village is a big family-Cheshire."

"[T]here is no such thing as society. There are individual men and women, and there are families." 3

The problem of industrial pollution has been a major impetus for the ascent of law and economics theory. ${ }^{4}$ Beginning with Pigou, ${ }^{5}$ law and

1. Telephone Interview with Jennifer Harrison, Town Clerk, Cheshire, Ohio (June 25, 2002) [hereinafter Harrison 1] (describing what the community was like before the buyout proposal). For those not familiar with the history of American television, Mayberry, North Carolina, was the bucolic fictional town featured on The Andy Griffith Show from 1960 to 1968. A spin-off, Mayberry, R.F.D., ran until 1971.

2. These words appeared on an embroidered sampler we observed in the home of Cheshire residents Jim and Eva Rife on February 10, 2003.

3. Interview by WOMEN's OwN with Margaret Thatcher, Prime Minister, United Kingdom (Oct. 31, 1987), reprinted in The Collected Speeches of Margaret Thatcher 576 n. 1 (Robin Harris ed., 1997). 
economics scholars have taken turns at tackling this issue, producing a voluminous body of theoretic literature. ${ }^{6}$ In large part, however, scholars have developed the theory through highly stylized examples or the analysis of a few classic legal cases, ${ }^{7}$ with relatively little attention paid to the complex behavioral responses that pollution cases engender in the real world. ${ }^{8} \mathrm{Al}-$ though the economic analysis of pollution has been enormously influential, in terms of both theory and policy, ${ }^{9}$ the analysis has been conducted entirely from a perspective of methodological individualism. That is, law and economics scholars see victims in pollution disputes as acting independently of each other, with no interdependencies and no sense of social embeddedness. Although we acknowledge that the Thatchcrite assumption of atomistic individualism can be powerful and productive in many cases, we argue that it is a highly incomplete description of human behavior, one that can be misleading in some important settings.

One such setting is the subject of this Article-the unprecedented buyout of the entire town of Cheshire, Ohio, by American Electric Power Company (AEP), whose large, coal-fired power plant, located at the edge of the town, was a significant source of the pollution affecting Cheshire residents. The Cheshire buyout presents a challenge to standard economic

4. See, e.g., Thomas W. Merrill \& Henry E. Smith, What Happened to Property in Law and Economics?, 111 YALE L.J. 357, 367-83 (2001) (discussing the centrality of pollution and nuisance disputes in the law and economics literature). For a broader environmental perspective on the problem of pollution, see William F. Baxter, People or Penguins: The Case for Optimal Pollution (1974).

5. Arthur C. Pigou, The Economics of Welfare 172-203 (4th ed. 1978) (proposing internalization of externalities by taxation).

6. We review the main contributions in Part II, infra.

7. Two real-world cases that substantially influenced law and economics scholarship were Boomer v. Atlantic Cement Co., 257 N.E.2d 870 (N.Y. 1970), in which the New York Court of Appeals denied pollution victims injunctive relief and instead awarded them damages, and Spur Industries, Inc. v. Del E. Webb Development Co., 494 P.2d 700 (Ariz. 1972), in which the Arizona Supreme Court enjoined a feedlot from continuing its operation but ordered that a developer representing residents indemnify the tortfeasor for the cost of moving or shutting down.

8. Robert C. Ellickson's Order Without LaW: How Neighbors Settle Disputes (1991), although not about pollution, is one exception. Another is Daniel Farber's extended study of the events in Boomer v. Atlantic Cement Co. in Property LaW and Legal Education 7 (Peter Hay \& Michael H. Hoeflich eds., 1988). William A. Fischel also has written about communities from a combined ethnographic-law and economics perspective. An example is his treatment of Scranton, Pennsylvania, in analyzing Pennsylvania Coal Co. v. Mahon in chapter I of Regulatory Takings: Law, ECONOMICS, AND POLITICS (1995). His recent work on the importance of local public schools as creators of social capital represents another significant effort to combine economic and legal analysis of communities. See William A. Fischel, An Economic Case Against Vouchers: Why Local Public Schools Are a Local Public Good (Dartmouth Coll., Working Paper No. 02-01, 2002) (arguing that local schools foster the development of social capital by facilitating interactions among parents).

9. Market-based environmental policies such as tradable emissions permits have significantly influenced policy and generated important efficiencies in pollution cleanup. See, e.g., Robert N. Stavins, Market-Based Environmental Policies, in Public Policies for Environmental. Protection (Paul R. Portney \& Robert N. Stavins eds., 2000). 
analysis, which predicts a bargaining failure in settings involving multiple victims because of holdout problems. ${ }^{10}$ Yet in Cheshire the polluter successfully transacted with ninety property owners without encountering any real holdouts.

In attempting to understand what happened in Cheshire, we spent nearly a year following the buyout as it unfolded. We visited the town, conducted interviews with residents and local journalists who covered the case, and tracked the story in the media. Our goals were to understand what accounted for the unusual outcome in Cheshire, to evaluate the merits of the buyout deal, and to explore the implications of this case for economic theory and legal policy.

This Article argues that the standard law and economics account, which ignores the importance of community, leads to errors in both the positive and normative analyses of what happened in Cheshire. In line with Robert Ellickson's investigation of Shasta County, California, this Article posits that what seems on first glance to be a neat Coasean solution to an externalities problem turns out, on closer examination, to look nothing like what conventional theory predicts. " This Article is about what happens to the law and economics of pollution control when one allows for the possibility that victims may have an interest in a common asset"community"- -that also is harmed by the polluter's actions. However, the lessons of this Article are not merely negative: it also demonstrates how the existence of communities can be incorporated into a law and economics framework, with important implications for tort, collective bargaining, and property theory.

Since publication of Ronald Coase's classic article The Problem of Social Cost ${ }^{12}$ economists have identified high transaction costs as the key

10. See, e.g., Guido Calabresi \& A. Douglas Melamed, Property Rules, Liability Rules, and Inalienability: One View of the Cathedral, 85 HaRv. L. Rev. 1089, 1119 (1972).

11. Ellickson, supra note 8. We wrote this Article in the spirit of Ellickson's pioneering ethnographic approach to law and economics. As with his epic study, our goal is to explore thc complex story of how a single community coped with a legal dispute and to demonstrate the theoretical significance of what happened on the ground.

Understanding the Cheshire buyout also may hold immediate practical importance, because there have been several reports of polluters attempting to induce similar buyouts elsewhere. See, e.g., Marego Athans, Elderly Residents, Town to Share Their Last Days, BALT. Sun, Nov. 11, 2002, at A1 (quoting residents of West Virginia, across the river from Cheshire, who are attempting to gcnerate a buyout by AEP for their properties); Jim Belshaw, Don't Fight It, Buy It, Albuquerque J., Aug. 14, 2002, at BI (suggesting that Intel should buy the town of Corrales, New Mexico, to solve pollution problems from its plant there); Rita Price, Residents of Village Near Power Plant Fear Repeat of Cheshire, Columbus DisP., June 16, 2002, at B10 (describing the town of Moscow, Ohio, located near a coal-fired electric plant using the same selective catalytic reduction (SCR) technology as AEP's General James M. Gavin Plant in Cheshire, and suggesting that some residents favored a buyout); Dale F. Sorget, Sempra Plan Spells Loss for Homeowners, South Bend TriB., Aug. 8, 2002, at Al1 (proposing that Sempra Energy buy homes near its plant in Lake Township, Michigan, that lost value because of the plant's construction and operation).

12. Ronald H. Coase, The Problem of Social Cost, 3 J.L. \& EcoN. 1 (1960). 
barrier to the efficient internalization of externalities such as pollution. The plant whose pollution was at issue in Cheshire comprises two of the world's largest coal-fired electric generators; it seems likely that the plant is worth much more to AEP than the town was to its occupants. The efficient solution to the problem of the plant's pollution is therefore not to shut down the plant but to "move" the town, and that is precisely what has happened.

According to Guido Calabresi and A. Douglas Melamed, however, in cases involving multiple parties, such as public nuisance cases, efficiency calls for liability rule protection: damages. ${ }^{13}$ In such instances, property rule protection, injunctive relief, would invariably create holdout or collective action problems that would thwart the efficient allocation of resources. ${ }^{14}$ Ensuring efficiency is the standard law and economics justification for the landmark case of Boomer v. Atlantic Cement Co. ${ }^{15}$ in which the New York Court of Appeals changed the nature of the residents' protection from injunction to damages.

A similar logic should have applied to Cheshire. For the plant to continue polluting, it had to buy out all the residents. Suppose each of the roughly ninety houses was worth $\$ 150,000$ to its owner (for a total of $\$ 13.5$ million), and that the cost of abating the pollution was $\$ 100$ million to AEP. There is thus a potential "surplus" from buying out the town of $\$ 100-\$ 13.5=\$ 86.5$ million. However, if eighty-nine home owners have already agreed to sell at $\$ 150,000$, the last owner can hold out for a much higher price-say, $\$ 50$ million-knowing that it will always be rational for AEP to pay this amount rather than forego whatever surplus it would get if it could close the deal. Because each home owner should reason in this way, the standard law and economics analysis suggests that what happened in Cheshire would never take place.

Although the standard account recognizes the possibility of multiple victims of pollution, it assumes nothing is at stake in a pollution dispute except the harms to individual property values or health. To the contrary, this Article is about what happens to the law and economics account of

13. See Calabresi \& Melamed, supra note 10, at $1125-27$; see also, e.g., RICHARD A. POSNER, ECONOMIC ANALYSIS OF LAW 56-57, 70 (5th ed. 1998) (discussing the conventional wisdom favoring property rules where transaction costs are low and liability rules where transaction costs are high).

14. See POSNER, supra note 13, at 69 (pointing out that "[t]he costs of transacting are highest when elements of bilateral monopoly coincide with a large number of parties to the transaction" and listing the case of "homeowners [who] have a right to be free from pollution" as the paradigmatic example).

Ellickson and Been report, however, that there appear to be many more land assemblages than theory would predict or than most scholars seem to believe. See Robert C. ElLICKSON \& VICKI L. BeEN, LAND USE CONTROLS, 1029-40 (2d ed. 2000). For an alternative mechanism for overcoming holdouts, see Michael A. Heller \& Rick M. Hills, The Art of Land Assembly (unpublished manuscript, on file with authors).

15. 257 N.E.2d 870 (N.Y. 1970). For a discussion of the theoretic significance of the case, see Abraham Bell \& Gideon Parchomovsky, Pliability Rules, 101 Mich. L. Rev. 1, 38-39 (2002). 
pollution control when we allow for the possibility that victims may have an interest in a common asset-community-that is also harmed by the polluter's actions.

That communities are valuable to people should come as no surprise. ${ }^{16}$ It is a key finding of a vast ethnographic literature and resonates well with common experience. ${ }^{17}$ Moreover, community is a special kind of asset, one whose value depends on the contributions of every individual who makes up the group. If one individual exits - for instance, because of the community's pollution problem-she diminishes the value of the community for all who remain. Hence, community is a kind of positive externality that can exercise a profound effect on the outcomes of economic transactions (including pollution disputes).

The circumstances surrounding the Cheshire buyout strongly support the idea that village residents valued the sense of community thcy found in Cheshire. The analysis that follows documents the significant ties many Cheshire residents-some with ancestral connections going back two hundred years - felt with their village. This Article suggests scveral explanations for what made the community so valuable to its residents and then

16. Of course, it has long been recognized that certain kinds of local public goods require many agents for their production. For example, collective action may be necessary to maintain irigation facilities, to conduct political activity to overturn Jim Crow laws, or to establish a town commons (and then to prevent overgrazing of cattle on the common property). Communities are thus useful for controlling the inefficiencies of collective action problems, which would otherwise lead atomistic individuals to free ride on the efforts of others or to overexploit commonly owned resources. See, e.g., Elinor Ostrom, Governing the Commons: The Evolution of Institutions for Collective ACTION (1990).

Communities are also valuable as a source of norms that ensure trustworthy behavior when legal sanctions are ineffective or unavailable, thereby allowing economically valuable transactions to take place. See Robert D. Putnam, Making Democracy Work: Civic Traditions in Modern Italy (1993); Lisa Bernstein, Opting Out of the Legal System: Extralegal Contractual Relations in the Diamond Industry, 21 J. LEGal STUD. I15, 116 (1992); Janet Tai Landa, $A$ Theory of the Ethnically Homogeneous Middleman Group: An Institutional Alternative to Contract Law, in Trust, ETHNicity, AND IDENTITY 101 (Janet Landa ed., 1994).

The downside is that communities may also enforce "bad" norms such as racial segregation. See, e.g., Hortense Powdermaker, After Freedom 23-55 (1939) (discussing cultural enforcement of Jim Crow norms); Richard H. McAdams, Cooperation and Conflict: The Economics of Group Status Production and Race Discrimination, 108 HARv. L. Rev. 1003, 1044-63 (1995) (same).

17. For a tiny sample, see Alan Ehrenhalt, The Lost City: Discovering the Forgotten VirTuEs OF COMMUNITY IN THE CHICAGO OF THE 1950s (1995) (reconstructing the texture of life in Chicago neighborhoods); KaI T. ERIKSON, EverythING IN ITS PATH (1978) (stressing the loss of community in Buffalo Creek, West Virginia, which was destroyed by flood); Robert D. Putnam, Bowling Alone: The Collapse and Revival of American Community (2000) (documenting statistically a decline in civic engagement); Isabel Wilkerson, 350 Feet Above Flood Ruins, a River Town Plots Rebirth, N.Y. Times, Oct. 31, 1993, at Al (recounting the story of Valmeyer, lllinois, which was bought out by the government because it was in the floodplain of the Mississippi River but that reconstituted itself on higher ground). Similar events occurred in Chelsea, lowa, where "[p]eople were split over whether to move away from this low spot beside the lowa River or to stay put" in the aftermath of serious flooding in 1993. See Monica Davey, lowa Town Survived Flood, but Teetered in the Aftermath, N.Y. Times, July 14, 2003, at Al (describing a breakdown in community when some residents left after the flood). 
argues that the significance of community explains important aspects of the Cheshire story that otherwise would be puzzling. In particular, it argues that the overlooked presence of "community externalities"--strong interdependence among the utility functions of residents of the village-can account for why essentially everyone in the village decided to sell, despite the conventional wisdom that bargaining with groups invariably leads to holdouts and other high transaction costs. Community ties also explain how the town was able to overcome the collective action problem that theory predicts should undermine attempts to organize any concerted political or legal struggle. Finally, community ties suggest that efficiency-minded policy makers should be wary of approving community buyouts. Even though the Cheshire deal was nominally voluntary, the buyout likely undercompensated at least some residents.

The Cheshire case holds five other implications for legal scholarship and policy that extend far beyond our case study. The first concerns the importance of law and legal doctrines in shaping bargaining. Law and economics scholars conventionally assume that settlement negotiations occur "in the shadow of the law," meaning that parties bargain to roughly the same result that would occur if the dispute were pursued to a final adjudication. ${ }^{18}$ In Cheshire, concerns about health risks, delays, the disappearance of community, and publicity were important motivating factors in residents' decisions. But little evidence exists that anyone decided to sell based on whether it was possible to get an injunction or merely sue for damages. In short, as Ellickson found in his study of Shasta County, California, ${ }^{19}$ formal law seemed to matter much less in Cheshire than did a number of other, more pressing forces.

A second implication is that when a community is not viable at a smaller scale than that at which it is currently operating, an offer to buy out some residents may cause the community to unravel, thus forcing all remaining home owners to sell. The process is analogous to coercive tender offers and to models of tipping and resegregation in the residential housing markets, as we explain below. ${ }^{20}$

Cheshire suggests a third insight which concerns the choice of remedies in nuisance disputes. Standard analysis of nuisance law treats the choice of remedy as beyond the control of the parties in the dispute. ${ }^{21}$ The decision whether to grant an injunction or damages lies exclusively with the court; the polluter and victims, through their actions, have no control over it. An important insight that emerges from this Article is that this

18. Robert H. Mnookin \& Lewis Komhauser, Bargaining in the Shadow of the Law: The Case of Divorce, 88 YALE L.J. 950 (1979). Settlement agreements should thus track legal entitlements, with the advantage that neither side has to bear the costs of litigation.

19. See Ellickson, supra note 8.

20. See infra Part IV.D.3.

21. See infra Part V. 
characterization may be inaccurate, at least as it relates to polluters. Polluters may preempt the possibility of an injunction by making an abovemarket buyout offer to the residents. If the majority of residents accept this offer, the polluter is in an excellent position to argue, if sued, that damages are fully compensatory, and thus no injunction should issue. ${ }^{22}$

This finding opens the door to the possibility of private takings. ${ }^{23}$ For example, a polluter could offer to buy $60 \%$ of the affected properties for an above-market price. ${ }^{24}$ If the remaining $40 \%$ of the town is not viable on its own, all residents will have an incentive to sell; indeed, they will compete for the right to sell to the polluter. Because the polluter eliminates the possibility of an injunction by buying $60 \%$ of the town, the remaining residents face the cost of a lawsuit with the prospect of obtaining compensation only for the value of their homes. ${ }^{25}$ Preempting an injunction by eliminating the potential of the residents to hold out guarantees a sale on terms advantageous to the polluter.

A fourth insight from the story of Cheshire is that residents may refuse to sell and yet not be holdouts in the typical sense. A classical holdout is a party who refuses to deal in a strategic attempt to extract rents. Two of the older residents of Cheshire did choose not to sell; as we will show, however, they do not fit the standard definition of a holdout. First, they continued to refuse to sell even after it was no longer possible to obtain an injunction. Second, both residents owned valuable riverfront land, and both had strong sentimental attachment to their properties. These residents arguably should not be labeled holdouts because they simply placed higher subjective value on their properties than AEP was willing or obligated to pay. Thus, this Article proposes that such people might better be termed "holdins."

A fifth insight from Cheshire is that analysis of community externalities suggests a revision in the law of takings. Currently, takings doctrine applies the same compensation rule to all exercises of eminent domain. The

22. See Developments in the Lau-lnjunctions, 78 HARv. L. REv. 994, 997-1021 (1965). Douglas Laycock suggests that this maxim is more honored in the breach than in the observance; the easier it is for plaintiffs to secure an injunction, however, the more perplexing it is that no one sought to do so in Cheshire. See Douglas Laycock, The Death of the Irrepara ble Injury Rule (1991).

23. It has been suggested that allowing a nuisance causer to pay damages rather than face an injunction permits an "inverse condemnation[, which] may not be invoked by a private person or corporation for private gain or advantage. Inverse condemnation should only be permitted when the public is primarily served in the taking or impairment of property." Boomer v. Atl. Cement Co., 257 N.E.2d 870, 876 (N.Y. 1970) (Jasen, J., dissenting) (internal citations omitted). For an excellent discussion of private takings, see Abraham Bell, Private Takings (unpublished S.J.D. dissertation, Harvard Law School) (on file with authors).

24. The polluter might also make an offer to buy $100 \%$ of the affected properties. Offering to buy a lower percentage induces competition among the sellers and increases the coercive element of tender offers. Of course, the polluter may announce that he is going to buy only $60 \%$, and then, if a larger percentage of residents agrees to sell, buy from them all.

25. See infra Part V. 
existing rule entitles owners of property taken by the government to receive fair market value; owners of adjoining properties are not eligible for compensation. Furthermore, the number of properties the government takes is irrelevant to the calculation. The uniform treatment of all takings may lead to gross undercompensation when community externalities exist. As an objective compensation measure, fair market value does not capture the value that property owners derive from living in a close-knit community. Worse yet, the existing rule offers no compensation for loss of community amenities to members whose property is not physically taken. ${ }^{26}$ Thus, when community externalities are strong, the current compensation regime not only is unfair but also may be inefficient. Because takers are not forced to internalize the full economic effect of their actions on communities, both the government and private corporations may transfer property interests from unconsenting individual owners to themselves, even when doing so creates a net welfare loss. To take account of community externalities, we devise a new typology of takings by dividing the universe of takings cases into three conceptual categories: isolated takings, tippings (in which the government condemns multiple properties in a community and thereby undermines its ability to continue to exist), and clearings (in which an entire community is uprooted). ${ }^{27}$ We then propose a differential compensation regime tailored to compensate communities for the full range of harms inflicted by exercises of eminent domain.

This Article consists of seven parts. Part I lays out the basic facts in the Cheshire case and explains the challenge it presents for standard economic analysis. Part II summarizes the law and economics literature on pollution. Part III analyzes in detail the legal rules that govern the allocation of responsibility for the pollution in Cheshire and assesses the likely remedies residents could have obtained if they had decided to pursue legal action against the polluter. A basic assumption of law and economics theory is that any alternative to litigation (such as the kind of settlement that occurred in Cheshire) will take place in the shadow of the legal rules allocating liability and defining remedies, so parties' perceptions of their legal rights will inevitably shape the outcome. Part IV documents the importance of community externalities in Cheshire and explains why a strong community is less likely than a weak community to generate strategic holdouts. The last three parts explore the importance of these findings for tort, collective action, and property theory. Part $\mathrm{V}$ argues that polluters can affect a court's choice of remedy in nuisance cases by making above-market buyout offers. If, as claimed, polluters can forestall the use of injunctive relief

26. See generally Abraham Bell \& Gideon Parchomovsky, Takings Reassessed, 87 VA. L. REv. 277 (2001) (exploring the effects of eminent domain on neighboring property owners).

27. For a classic discussion of clearings, see Berman v. Parker, 348 U.S. 26 (1954) (addressing the condemnation of land for redevelopment under the District of Columbia Redevelopment Act). 
by making attractive buyout offers, this opens the door to the possibility of private takings, situations in which polluters can in effect force property owners to sell to them. Part VI explores a mechanism for resolving collective action problems in group negotiations. Part VII concludes the Article by incorporating the insights from Cheshire into a noveI framework for assessing takings compensation.

\section{I \\ The Story OF CHeshire}

The town of Cheshire was founded in $1834 .{ }^{28}$ Located in southern Ohio, on the banks of the Ohio River near West Virginia, it was a small village, with about 220 inhabitants (roughly ninety families) spread over sixteen acres, with one pizza parlor, one stoplight, and one gas station. Its nearest neighboring town was roughly seven miles away.

At the edge of town is a coal-fired electricity-generating plant, the General James M. Gavin Plant, owned by AEP.

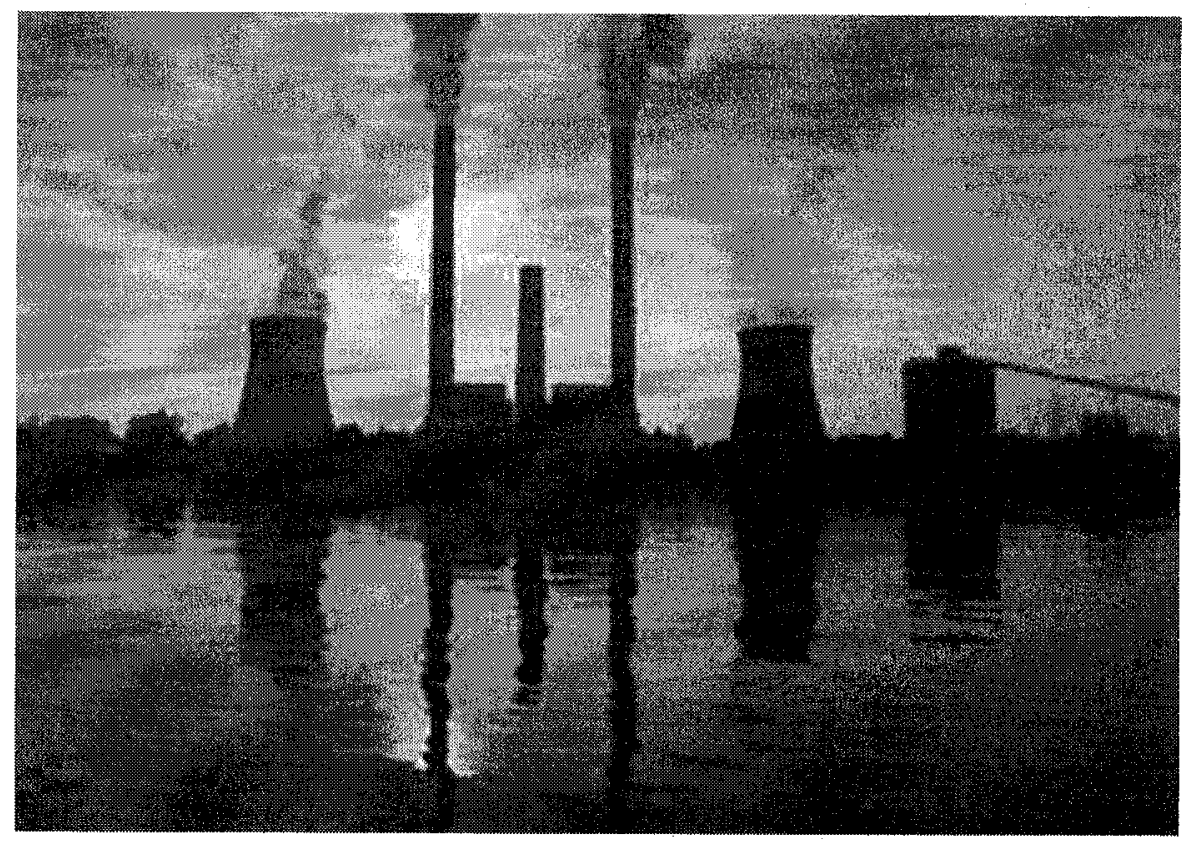

\section{The Gavin Plant ${ }^{29}$}

28. See Stephen Buckley, Lights Out in Cheshire, St. Petersburg Times, Nov. 10, 2002, at 1A.

29. The visible discharge coming from the stacks is largely water vapor. Photograph available at http:/www.dispatch.com/news/news02/jun02/cheshiregallery/pages $/ 8 \mathrm{cheshire} 350 \times 245 . \mathrm{htm}$. Copyright (c) 2003 The Columbus Dispatch. Reprinted with permission of the publisher: 
The plant is one of the largest of its kind in the world, and AEP is one of the biggest firms in the United States, with revenues of $\$ 60$ billion in 2001 . The plant's massive scale of operations is difficult to describe in words; only after visiting the place were we able to appreciate its "brooding omnipresence." 30 Surprisingly, given the small size of the town and the large size of the plant, only one resident of Cheshire worked at the Gavin Plant as of 2002.

\section{A. The Gavin Plant's Pollution}

The Gavin Plant has long been a significant source of emissions. According to records of the U.S. Environmental Protection Agency (EPA), "[b]efore recent efforts to curb pollution, Gavin was the nation's largest source of sulfur dioxide, the main ingredient in acid rain . . ."31 The Gavin Plant also held the dubious distinction of leading the nation in "emissions of nitrogen oxide, which creates smog, and was one of the leading sources of carbon dioxide." 32 This record prompted AEP to take action that significantly reduced total emissions. ${ }^{33}$ The plant's efforts notwithstanding, "[d]uring 2001, Gavin ranked seventh in the nation among power plants for total emissions of carbon dioxide and 18 th for nitrogen dioxide . . ."34

Unfortunately, the very actions that have led to a drop in the level of total emissions have concentrated the remaining pollution on the plant's nearby surroundings. Jennifer Harrison, the town clerk and a Cheshire resident, stated that before 1995, the main problems were occasional fallout, which ate through paint on vehicles, and excessive noise of up to $140 \mathrm{deci}$ bels from exhaust fans, which AEP eventually mitigated by installing mufflers. ${ }^{35}$ She said she had an insurance claim for paint damage every year, and dirt was always a problem. "In 1995," however, "things got worse. That's when AEP . . . lowered the [height of the] stacks from 1,100 to 800 feet." ${ }^{36}$ Even then, only one resident sued, and his claim was settled. ${ }^{37}$

30. S. Pac. Co. v. Jensen, 244 U.S. 205, 222 (1917) (Holmes, J., dissenting) (demystifying the common law).

31. Michael Hawthome, Cheshire: Death of a Village, Columbus DisP., Nov. 10, 2002, at A1.

32. Id.

33. Id. For example, "[t]he plant released about 5 pounds of sulfur dioxide for every megawatt hour of electricity it generated [in 2001], down sharply from the 56 pounds per megawat hour it released in 1990." Id.

34. Id.

35. Interview with Jennifer Harrison, Town Clerk, Cheshire, Ohio (Feb. 10, 2003) [hereinafter Harrison 11]

36. Harrison 1, supra note 1. Before the blue plume problem, which arose at a later time, there “"wasn't anything that was a problem to us,' said Charles Reynolds, 57, who owns the bait shop." Stephanie Simon, To Holdouts, Offer to Buy Town ls Dust in Wind, L.A. T1mes, Aug. 25, 2002, at Al In the summer of 2001 , however, "locals did notice a problem, touched off ironically when the utility installed new pollution control equipment." Id.

37. Harrison I, supra note 1 . 
To be fair to AEP, it is imperative to note that regulatory intervention apparently forestalled an alternative method of reducing emissions of sulfur dioxide. Around 1989, in response to tougher pollution standards,

AEP ... planned to switch to low-sulfur, out-of-state coal at Gavin, which it said would be less expensive. Faced with political pressure from the state's mining interests, the Public Utilities Commission gave AEP a choice: Absorb the cost of switching fuel sources, or charge ratepayers to install scrubbers designed to reduce sulfur pollution from Ohio coal. ${ }^{38}$

If AEP had been able to use low-sulfur coal, the blue plume problem that was to later arise would likely have been much less severe. ${ }^{39}$ Denied this alternative, however, AEP resorted to a different, technological solution.

In 2001, the plant installed a new selective catalytic reduction (SCR) scrubber system designed to ensure that emissions of nitrogen oxide would comply with the EPA's 2003 requirements for coal-fired power plants. ${ }^{40}$ After it was installed, however, it became clear that although it reduced nitrogen oxide emissions, the SCR actually increased emissions of sulfur trioxides. ${ }^{41}$ The increased sulfur trioxide emissions were apparently caused by a complex interaction between the new scrubber and another antipollution mechanism at the plant that was supposed to remove sulfur from the gases formed when coal was burned. ${ }^{42}$

38. See Hawthorne, supra note 31. If regulators had treated the cost of installing scrubbers as a capital expenditure, AEP would have been allowed to increase its "installed base" by the cost of the scrubbers, and therefore could have passed this cost on to its consumers in the form of higher prices to cover this expense. Because regulators threatened not to treat the scrubbers as a capital expenditure, however, AEP would have had to pay for them out of shareholder profits as an operating expense, which obviously made installation of scrubbers a very unattractive proposition. That environmental regulators might prefer a more costly method of achieving a clean environment is not a new conclusion. For a pioneering analysis of the political economy of air quality regulation, see BRUCE A. ACKERMAN \& William T. Hassler, Clean Coal/DirTy Air (1981) (arguing that the EPA enforced the Clean Air Act in such a way as to protect the eastern coal industry and its dirtier coal at the expense of western coal producers).

39. According to Jennifer Harrison, AEP experimented with low-sulfur coal in the summer of 2002, with favorable results. See Harrison Il, supra note 35.

40. According to AEP's Web site, the technology had been used safely worldwide since the mid1980 s and was the only postcombustion technology that would achieve the EPA's emission standards. The SCR works by mixing ammonia into the plant's exhaust gases. In the presence of a catalyst, the SCR is able to remove more than $90 \%$ of the nitrogen oxide. See Press Release, American Electric Power, AEP to Buy Property near Gavin Plant; Will Use Space for Enhancements (Apr. 16, 2002), available at http://www.aep.com/newsroom/newsreleases/default.asp?dbcommand=DisplayRelease\& $\mathrm{ID}=896 \&$ Section=Corporate\&colorControl=on.

41. See Agency for Toxic Substances and Disease Registry, ToxFAQs for Sulfur Trioxide and Sulfuric Acid (June 1999), at http://www.atsdr.cdc.gov/tfacts117.html (last visited Nov. 3, 2003) ("SO [sulfur trioxide] forms sulfuric acid when it comes in contact with water. Sulfuric acid can cause burns to the skin, eyes, lungs, and digestive tract. ... EPA limits the amount of sulfur dioxide that can be released into the air. This limits the amount of sulfur trioxide and sulfuric acid that form from sulfur dioxide in the air.").

42. The new SCRs were originally designed to be run using 360,000 gallons of anhydrous ammonia, which was to be stored in liquid form in large tanks at the plant. Residents were told that if a 
Even though the plant has an 830 -foot smoke stack, under certain weather conditions the sulfur trioxides formed a bluish plume that settled over the town. During the summer of 2001, this plume caused a variety of symptoms in many Cheshire residents. Some "people [developed] sores on their lips and tongues, nausea, vomiting and headaches." ${ }^{.43}$ Others complained of "burning eyes, blistered lips, nagging coughs and burn marks on their cars." On some muggy days, "they would spot a blue haze hovering over the village, like exhaust from an alien spacecraft."

AEP claimed that "at no time during the plant's operation did emissions in the plume exceed any health-based ambient air quality standards or permissible exposure limits established by federal or state regulations." ${ }^{\text {"45 }}$ An AEP spokesman, Pat Hemlepp, denied " "[t]here has been [any]... long term health impact, just a short term impact. Any attempt to sue on health grounds would have [sic] a slam dunk for us because all of the monitoring has shown it is not an issue." ${ }^{\prime 46}$ And yet, a monitor installed by the EPA in Cheshire's town hall had to be recalibrated because on particularly bad days, sulfur dioxide levels exceeded the machine's measurement capability. ${ }^{47}$

Setting aside the issue of whether emissions actually exceeded the regulatory limits, ${ }^{48}$ the company did attempt to devise a technical solution

tank began to leak, "they would have 6 minutes to evacuate or everyone would die." Harrison 11, supra note 35 . In the end, pursuant to lobbying from residents, the plant decided to use a safer, urea-based technology. $I d$.

43. Harrison I, supra note 1. Newspaper reports from other residents confirmed these details. For decades, folks [in Cheshire] have looked out at the smokestacks from their vegetable gardens and their backyard swings, from the schoolyard, from the playground. The vapors smearing the sky have been as much a part of the local landscape as the Ohio River. And few have given it much thought.

Simon, supra note 36 , at A1.

44. Simon, supra note 36 , at A1.

45. Press Release, American Electric Power, AEP Will Invest $\$ 7$ Million to Address Community Concerns over Plume Appearance at Gavin Plant (Jan. 31, 2002), available at http:/www.aep.com/ newsroom/newsreleases/default.asp?dbcommand $=$ DisplayRelease \&ID $=887 \&$ Section=Environmental\& colorControl=on (attributing this point to John F. Norris Jr., AEP's senior vice president of operations and technical services). As to the air quality standards at issue, the EPA has stated that

The primary NAAQS [National Ambient Air Quality Standards] for sulfur oxides, measured as $\mathrm{SO}_{2}$ [sulfur dioxides], are 0.14 parts per million (ppm), or 365 micrograms per cubic meter $\left(\mu \mathrm{g} / \mathrm{m}^{3}\right)$, averaged over a period of 24 hours and not to be exceeded more than once per year, and an annual standard of $0.030 \mathrm{ppm}$, or $80 \mu \mathrm{g} / \mathrm{m}^{3}$ never to be exceeded. The secondary standard for $\mathrm{SO}_{2}$ is $0.50 \mathrm{ppm}$, or $1300 \mu \mathrm{g} / \mathrm{m}^{3}$ averaged over a three-hour period. The secondary standard may not be exceeded more than once per year.

EPA Approval and Promulgation of Air Quality Implementation Plans; Pennsylvania; Revision to the State Implementation Plan (SIP) Addressing Sulfur Dioxide in Philadelphia County, 67 Fed. Reg. 57,156 (Sept. 9, 2002) (to be codified at 40 C.F.R. pt. 52).

46. David Teather, Smoke, Tears, Anger-Then Emptiness-in the Village Bought by a Power Company, The Guardian, May 14, 2002, at 3.

47. Interview with Ron Hammond, Cheshire schoolteacher, in Cheshire, Ohio (Feb. 10, 2003); Harrison II, supra note 35.

48. Harrison suggested that " $[\mathrm{t}]$ he standard is 5 particles [sic]/billion. At times, it has gone up to 300-700 particles [sic]/billion." Harrison I, supra note 1 . 
to the problem. In a January 2002 press release, AEP suggested it had developed a technique (involving the injection of water, magnesium hydroxide, and calcium hydroxide into the plant's emissions) that would "produce the chemical changes required to reduce $\mathrm{SO}_{3}$ [sulfur trioxide] levels." 49 These modifications were supposed to cost about $\$ 7$ million (for only one of the two units at the Gavin Plant).$^{50}$ However, residents expressed some doubt about the technological efficacy of this solution. ${ }^{51}$

\section{B. A Buyout Emerges from the Smoke}

In the meantime, many residents of Cheshire remained concerned about the health risks to which they had already been exposed and worried about future exposure. ${ }^{52}$ Residents complained to the EPA, and in 2000 the Agency accused the plant of violating the Clean Air Act, an accusation AEP denied. ${ }^{53}$ A subsequent investigation by the Agency for Toxic Substances and Disease Registry found the plant's emissions did "pose a public health hazard to some residents, particularly residents with asthma," but concluded that there were no documented long-term health effects. ${ }^{54}$

The precise history of the buyout negotiations is somewhat murky. In particular, it is difficult to identify the "Coasean moment" at which the deal was conceived. Initially, the residents' focus was litigation; it was for this purpose that they engaged a team of environmental lawyers. ${ }^{55}$ According to one source, the buyout proposal emerged out of a series of emails from the

49. Press Release, American Electric Power, supra note 45.

50. Id. The plan was to install the modifications at only one of the units to determine their efficacy and cost. AEP would equip the next unit only after reviewing the results from the first. According to an EPA press release of May 2002, "AEP, which is now using high sulfur coal, has ... agreed to stockpile low sulfur coal before it starts operating its SCR. If the injections fail to control the sulfuric acid emissions, AEP will promptly switch to low sulfur coal or implement any other equally effective short term measure." Press Release, Environmental Protection Agency, EPA, Ohio EPA Reach Agreement with AEP Gavin Plant (May 8, 2002), available at http://www.epa.gov/ Region5/news/news02/02opa062.htm.

5I. Ron Hammond pointed out to us that this solution had been tried only in European plants operating on a smallcr scale and with a different scrubber technology. The Gavin Plant's significantly "wetter" process, according to Hammond, made it a poor candidate for this solution. Hammond, supra note 47.

52. Hammond expressed concern about future health effects in an interview aired on a radio program.

1 get out the door and I look at the plume, you know, to see what's happening. I want my daughters to get out and play in the summer. I check the sulfur dioxide monitor to see if it's safe for them to play outside. And if it's not, you tell two little girls ages seven-and Emily almost I0-“"It's a bcautiful day outside, but you can't go out and play."

Analysis: Ohio Power Plant Buying Out Homes in Cheshire (National Public Radio broadcast, June 24, 2002).

53. See Katharine Q. Seelye, Utility Buys Town It Choked, Lock, Stock and Blue Plume, N.Y. TIMES, May 13, 2002, at Al ("At this point, the company is not even in violation of E.P.A. rules.").

54. Id.

55. Hammond, supra note 47. The team of lawyers was led by Richard Ayres, Barry Neuman, and Kathy Bailey, all of whom declined numerous invitations to speak to us. 
residents to AEP, and was as much an expression of frustration as a serious offer. ${ }^{56}$ Residents apparently expressed shock when their lawyers came back from meeting with AEP with a buyout proposal, although the buyout had been rumored for some time..$^{57}$

AEP ultimately agreed to pay roughly $\$ 15$ million for the town, and about $\$ 4.5$ million to the residents' lawyers. According to the company, the purpose of the deal was to enable expansion of the plant's facilities, including a new dock and coal storage space. ${ }^{58}$ The company adamantly denied any liability for pollution and framed the deal only as a way of securing the needed space. ${ }^{59}$ Yet residents had to waive all future claims against AEP as part of the buyout. The company's position is that the terms of the settlement that barred residents from suing the company for damage to past or future health were "just the lawyers doing their jobs" and played no role in the negotiations. ${ }^{60}$

The exact formula for computing compensation has not been disclosed, and residents and their attorneys will not discuss the specifics. The following terms are publicly known:

(1) Payment was made based on 1999 tax assessments. Sellers received a minimum of $\$ 100,000$ per property, with prices ranging from two to three and a half times the 1999 assessed value. ${ }^{61}$ It appears that no properties in Cheshire had been sold during the two or three years preceding the buyout, in large part because no one wished to move into the town, given the uncertainty about the pollution and attendant health risks. ${ }^{62}$

(2) AEP did not insist that everyone sell. However, the deal apparently contained a requirement that more than half of the

56. Id.

57. Id.; Harrison II, supra note 35. It is noteworthy that all parties involved had a stake in keeping the exact details of the negotiation process cloudy. Furthermore, all maintained that the initial proposal came from the residents. We discuss the significance of this detail in Part V1, infra.

58. Press Release, American Electric Power, supra note 40.

59. According to one reporter, "[s]ince the closing of a nearby coal mine in Meigs County that had supplied Gavin with six million tons each year, the coal-burning plant has increased its river traffic by some 3,500 barges a year, company officials say. Meigs coal arrived by land; its replacement comes by river." Rita Price, Watery Highway: The Ohio River Holds Tight the Hearts of Those Who Work, Live Along Its Banks, Columbus DisP., Sept. 1, 2002, at B1.

The company may have had many reasons besides the obvious reason of reducing its pollution liability to describe the buyout as a plan to allow expansion of the plant. A site-specific expansion rationale limits the precedential value of the sale and reduces the likelihood that communities located near other AEP plants could seek similar treatment. Moreover, the expansion rationale offered a reason for the company's unwillingness to buy properties just outside the town limits, where the health risk was presumably no less than that inside the town itself.

60. Teather, supra note 46.

61. Mary Beth Lane, Cheshire Land Buyout: Village Holdouts May Derail Agreement, Columbus DisP., Sept. 14, 2002, at AI.

62. Harrison 1, supra note I. Harrison noted that the housing market was "abysmal." Houses had been on the market for two or three years and did not sell. In the past (before 1995) there was a normal real estate market. 
residents tender their land before the purchase offer would become binding on the buyer. ${ }^{63}$

(3) Residents who wished to remain in their homes could sell and retain a life estate. This arrangement was apparently conditioned on their not staying away from Cheshire for more than 119 days in any year, which would result in forfeiture of the life estate. ${ }^{64}$

(4) Purchases were contingent on residents signing a waiver for any past health damage caused by exposure to emissions from the plant, either from the blue plume or previously. ${ }^{65}$

Ultimately, all but two resident and four nonresident property owners agreed to sell. In addition, roughly ten to twelve elderly residents sold but elected to remain in their homes for the duration of their lives. The two resident owners who chose to stay were long-term Cheshirites who apparently placed very high subjective values on their land or houses. ${ }^{66}$ Most of those who sold purchased new homes in the general area. ${ }^{67}$ However, unlike some other towns that have been dissolved, the residents of Cheshire did not agree to move en masse to a new location. ${ }^{68}$ Finally, despite the buyout, residents voted overwhelmingly not to dissolve the town government, so technically Cheshire still exists and will be governed by its roughly fifteen remaining residents. ${ }^{69}$

The Cheshire buyout presents several anomalies for conventional economic theorizing about torts involving multiple victims. First and foremost, the Cheshire buyout was simply not supposed to happen. The deal involved more than ninety sellers and a single buyer, a setting that according to theoretic predictions should have been rife with holdouts. Yet the deal went forward relatively smoothly, without any apparent holdouts (in the

63. Id.

64. Harrison II, supra note 35. Given that most residents who opted for this arrangement are elderly and might need extended medical care, the requirement of continued presence could have farreaching effects on the life estate tenants.

65. Todd J. Gillman, After Blue Clouds Enveloped Town, Power Plant Will Buy It for \$20 Million, Dallas Morning News, May 10, 2002.

66. We discuss these cases in Part VI, infra.

67. Aceording to one reporter, "several families plan to remain within breathing distance of the plant's emissions when they move out of Cheshire." Simon, supra note 36, at Al. Few residents moved more than twenty miles away. Harrison II, supra note 35 .

68. The case of VaImeyer, Illinois, which relocated on higher ground to avoid flooding from the Mississippi, is one example. See Wilkerson, supra note 17.

69. Cheshire is funded by the State of Ohio on a five-year basis, and its revenues are guaranteed for another four years. Hammond, supra note 47; Harrison Il, supra note 35 . Hence, the village can continue to operate for at least that long, even with a diminished tax base. There are additional administrative constraints, however: state law requires that the village have at least six elected eouncilors and an elected mayor, four of whom must be present to conduct business. An appointed financial officer may replaee the town clerk. Harrison II, supra note 35. 
economic sense of the term). ${ }^{70}$ Second, the sell-off raises important questions of economic efficiency. Commentators and courts usually presume that voluntary transactions benefit all parties involved. Yet the case of Cheshire suggests that at least some sellers tendered their property only because they feared it would become worthless unless they. sold immediately. In other words, although seemingly voluntary, at least some of the sales likely involved a coercive element, which casts doubt on the efficiency of the deal. Finally, theory suggests that a free rider or collective action problem should undermine residents' efforts to lobby for and negotiate a deal with AEP. These problems did not occur in Cheshire.

The remainder of this Article is dedicated to theoretic discussion of these and other challenges raised by Cheshire's story. We commence with a review of the economic analysis of pollution disputes, as it has evolved to date.

\section{II}

\section{The ECONOMIC TheORY OF NUISANCE LAW}

The problem of pollution has long preoccupied economic theorists and policy makers. Because the benefits of the pollution-producing activity go solely to the polluter, while the costs of pollution are distributed to its victims or to society at large, pollution is a classic example of an externality or market failure. Hence, rational, seIf-interested polluters will underinvest in abatement efforts. At least at first glance, it appears that a laissezfaire world will therefore have an inefficiently high level of pollution; society will be forced to endure pollution that has harms in excess of its abatement costs. $^{71}$

A.C. Pigou was the first economist to address the challenge of misaligned incentives posed by pollution. ${ }^{72}$ His solution to the externality created by pollution was to make the polluter pay the full social cost of her actions by imposing a tax on emissions. ${ }^{73}$ If the factory emitted one hundred tons of pollution, with a social harm of one dollar per ton, then a tax of one dollar per ton would force the polluter to "internalize" the true social costs of its behavior. With the tax in place, a ten-dollar investment in a

70. We discuss the difference between the economic definition and the colloquial use of the term in Part VI, infra. Of course, it is impossible to rule out the possibility that the resident owners who remained will decide, at the end, to sell to AEP at a premium over the collective deal.

71. A simple numeric example helps illustratc why this result obtains. Suppose the polluter could install a scrubber that would completely eliminate all pollution. The cost of the scrubber is ten dollars, while the cost of the pollution to its victims is one hundred dollars. Even though society as a whole would realize a net gain of ninety dollars from installing the scrubber, the polluter would gain only a negligible individual benefit from doing so and would need to incur the full ten-dollar cost. Consequently, the polluter would not install the scrubber, even though it would be welfare enhancing to do so: the pollution is therefore inefficient

72. Pigou, supra note 5, at I 72-220.

73. Id. 
scrubber now looks like a good deal to the polluter; instead of saving society one hundred dollars in pollution damages, the scrubber saves the polluter herself one hundred dollars in pollution tax liability, for a net savings of ninety dollars. ${ }^{74}$ Essentially, Pigou understood pollution as a public problem necessitating a regulatory solution.

Ronald Coase challenged Pigou's characterization of pollution in his classic article The Problem of Social Cost. ${ }^{75}$ Coase made two important contributions to the analysis of the pollution question. First, he realized that nuisance law, with appropriate damages, could serve the same function as a Pigouvian tax on pollution. ${ }^{76}$ Instead of the government implementing a tax at the appropriate rate, the nuisance law solution requires that a court make the polluter pay the full cost of his pollution as damages to the victimplaintiffs. ${ }^{77}$ In this way, the polluter once again is made to internalize the full harm of the pollution and will thus clean up pollution as long as it is cheaper to do so than to pay damages. ${ }^{78}$

Coase's second major insight reconceived pollution as a private bargaining problem rather than an issue for public regulation. Suppose that pollution is cheap to clean up and costly to its victims but that for some reason a court does not deem the pollution a nuisance. Even though the polluter is under no legal obligation to cease polluting, Coase realized that when bargaining is costless, the parties will have an incentive to strike a deal under which the polluter eliminates the pollution in exchange for payment from the victims. ${ }^{79}$ If a court finds the pollution to be a nuisance,

74. Although the tax "solves" the externality problem in a technical sense, it does so only by finessing some difficult implementation issues. First, the government must be able to monitor the amount of smoke the polluter emits so it can properly define the tax "base." A second, even more difficult challenge has been the source of considerable academic skepticism. To send the correct signal to the polluter, the government must be able to set the correct tax rate. Determining the correct tax rate requires complete information about the social harms created by a ton of emissions. Victims of pollution are heterogeneous in terms of their sensitivity to its effects. Some victims can presumably mitigate the harms to themselves at relatively low cost-for instance, by installing air filters or painting their houses more often. Others face more serious health consequences that are almost impossible to mitigate except by moving beyond the pollution's reach. Hence, valuing the social harm of pollution is extremely difficult. Moreover, the costs of pollution are likely to vary with the amount of emissions. The effect of the first ton of pollution may be higher or lower than the effect of the hundredth ton, and the appropriate pollution tax requires that we price each ton at its marginal cost. In short, Pigou's solution, while technically appealing, places a severe informational burden on the regulatory apparatus-a burden most economists have concluded is very difficult for regulators to carry.

75. Coase, supra note 12 .

76. Id.

77. Id.

78. Id. Again, however, the informational requirements involved in this "solution" are not to be slighted: courts must be able to determine the victim-plaintiff's damages correctly and consider all victims' costs, even if not all decide to litigate against the offending polluter.

79. Id. The assumed inefficiency of the pollution guarantees that there is a price-less than the victim's harm from the pollution and more than the costs of cleaning it up-at which a mutually beneficial cleanup deal can be struck. In the above scenario, even if the polluter had the legal right to continue polluting, the victim or victims could offer the polluter some amount between ten dollars (the 
the payment of damages (or the granting of an injunction) will also cause the pollution to cease. ${ }^{80}$

Although Coase dispensed with the difficult valuation problems inherent in the Pigouvian approach, he did so only by substituting an equally intractable problem - that of transaction costs. Transaction costs are notoriously difficult to define, but one can think of them as anything that impedes private bargaining between two or more parties. They might include the costs of determining those with whom one needs to negotiate, ${ }^{81}$ the costs of reaching an agreement, ${ }^{82}$ and the costs of enforcement, as well as the costs imposed by strategic behavior as each side haggles for the most favorable outcome. ${ }^{83}$ As Coase was the first to admit, in a world of high transaction costs, parties will not be able to bargain for an efficient level of pollution because the costs of reaching a deal may exceed any gains from the deal itself. In such a setting, some other kind of solution to the pollution problem must be found.

Coase's main insight was negative: in a world without transaction costs, both regulation and legal liability would be redundant. He offered little guidance on either the role or the design of legal rules when the cost of transacting is positive. Calabresi and Melamed then extended the Coasean insight by exploring the role of legal institutions in a world with positive transaction costs. ${ }^{84}$ They observed that the law performs two different functions: allocating entitlements to resources and determining how such resources are to be protected. ${ }^{85}$ In addressing the question of protection, Calabresi and Melamed focused on the choice between injunctive relief and damages-labeling the former a "property rule" and the latter a "liability rule." Drawing on Coase's work, Calabresi and Melamed proposed that injunctive relief should be favored when transaction costs are low, and damages should be preferred when transaction costs are high.

scrubber cost) and one hundred dollars (the pollution cost) to install the scrubber. The elimination of pollution for any payment in this range would leave both parties better off than before the deal.

80. Efficiency also obtains when the costs of cleanup are one hundred dollars and the benefits are only ten dollars, so it is now efficient to continue polluting rather than clean up. Even if the victims are granted an injunction that closes down the plant, the polluter will offer them something between ten and one hundred dollars to allow the pollution to continue, and both parties will be better off.

A further advantage of private bargaining is that it eliminates the need for courts or regulators to value either the harms to victims or the cost of cleaning up the pollution. Victims can arguably assess for themselves how much they would be willing to pay to eliminate or reduce pollution, and the polluter can assess how much it will cost to eliminate the emissions in question. Hence, both parties can strike a deal on their own when it is in their interests to do so.

81. See generally Oliver E. Williamson, The Economic Institutions of Capitalism 20-22 (1985).

82. Id.

83. See Robert Cooter, The Cost of Coase, 11 J. LeGal STUd. I, 23 (1982) (observing that strategic bargaining may thwart efficient allocation of resources).

84. See Calabresi \& Melamed, supra note 10, at 1089-93.

85. Id.

86. Id. 
Their rationale was that when the cost of transacting is sufficiently low, the party subject to the injunction will buy the entitlement from its holder if she values the entitlement more highly. ${ }^{87}$ When transaction costs are high, on the other hand, optimal allocation through bargaining is not possible, and courts should award damages to allow the liable party to choose between paying damages and ceasing the harmful behavior, whichever is less expensive. ${ }^{88}$

In the post-Coasean world, then, the crucial question for legal policy becomes what determines the amount of transaction costs. Although there is no definitive answer, the consensus view in law and economics is clear on at least one issue: transaction costs should increase as the number of parties in the negotiations increases. Robert Cooter and Thomas Ulen's textbook, for example, lists large numbers of parties as a factor promoting high transaction costs ${ }^{89} \mathrm{~A}$. Mitchell Polinsky arrived at a similar conclusion in his article on the economics of nuisance law, suggesting that when the number of victims is large, bargaining between polluter and victims is essentially impossible..$^{90}$ Elizabeth Hoffman and Matthew Spitzer make the same claim: more parties increase the amount of transaction costs. ${ }^{91}$

Large numbers generate high transaction costs for two reasons. First, the presence of many parties makes coordination difficult. Consider a polluter who wishes to buy permission to pollute from all those affected by his factory's smoke. The more victims there are, the harder it is to locate them all and to screen out actual victims from those who are not affected. Once the victims are identified, the process of negotiating deals with all of them, or of creating a single representative for the victim class as a whole, remains. Also, more victims might increase the heterogeneity within the victim class, which may make negotiating agreements problematic.

A second obstacle to holding down transaction costs is the holdout problem to which we alluded earlier. Holdouts have pride of place in economic theory. Transaction costs economics predicts that bargaining with a large number of entitlement holders, each of whom could veto the entire project, will invariably create a holdout problem. This problem arises because each seller is the marginal claimant for the entire deal and, as such, has the power to extract the full bargaining surplus. Suppose that to

87. Such bargains guarantee efficiency, for reasons outlined earlier. See analysis of Coase, supra.

88. As long as victims' harms are greater than the polluter's cleanup costs (i.e., the pollution is inefficient), damages set at any amount greater than the cleanup costs guarantee efficiency. Such damages make it cheaper for the polluter to clean up than to pollute and pay damages.

89. See Robert Cooter \& Thomas Ulen, Law and Economics 86 tbl.4.3 (2d ed. 1997).

90. Hence, neither private damages nor injunctions are effective remedies when there are multiple vietims. Instead, class action litigation (or perhaps public enforcement) should be preferred. See A. Mitchell Polinsky, Resolving Nuisance Disputes: The Simple Economics of Injunctive and Damage Remedies, 32 STAN. L. REv. 1075, 1109 (1980).

91. Elizabeth Hoffman \& Matthew L. Spitzer, Experimental Tests of the Coase Theorem with Large Bargaining Groups, 15 J. LEGAL STUD. 149, 150 (1986). 
construct a new residential development, the builder needs to acquire ten adjoining properties. The deal is worth $\$ 10$ million to the builder, and each resident values her property at $\$ 100,000$. Given that the bargaining surplus is $\$ 9$ million, the project is welfare enhancing and therefore should be undertaken. However, each resident knows that if the nine others agreed to sell for $\$ 100,000$, she could extract up to $\$ 9.1$ million-thc builder's entire surplus from the project. Reasoning backward, each resident would strive to be the last person to sign on, leading to failure of the project. Anticipating this dynamic, buyers would normally abstain from negotiating with groups, because such negotiations are likely to generate high transaction costs with little hope of success.

Although it is commonly asserted that holdouts are more likely as the number of parties increases, the rationale for this view is not entirely clear. So, for example, Calabresi and Melamed suggest that where "we enjoin Taney and there are 10,000 injured Marshalls," there will likely be holdouts whose presence would make it impossible for all the Marshalls to agree to allow Taney to continue his nuisance, even though it would be efficient to do so. ${ }^{92}$ Hoffman and Spitzer agree, suggesting that "[a]s a theoretical matter, thcre is reason to believe that the parties will likely fail to exhaust the gains from voluntary trade as the number of parties increases, because the problem with holdouts becomes more acute." ${ }^{\prime 93}$

We summarize the conventional wisdom about how to deal with nuisance problems in the first row of Table 1. With few parties, theory suggests that transaction costs should be low and hence that private bargaining between the polluter and his victims is feasible. In these circumstances, assigning the right to pollute (or to be free of pollution) to either side via a property rule, thus avoiding the need for a court to calculate damages, will produce an efficient result through a trade of entitlement for money. With many parties, theory predicts that transaction costs will be high, so bargaining between the parties is unlikely to be feasible. Hence, courts should

92. Calabresi \& Melamed, supra note 10 , at 1119.

93. Hoffman \& Spitzer, supra note 91, at 150. Their proof of this assertion assumes that the population at large consists of a large number of individuals, of whom $g \%$ are greedy and $1-g \%$ are "reasonable." (Greedy persons always hold out, whereas reasonable ones always accept a "fair" bargain.) See id. It is then obvious that the probability that at least one greedy person will be found in a random sample of size $N$ increases as the sample size increases. Hence, holdouts are more frequent in larger groups. Of course, Hoffman and Spitzer's "explanation" for this result boils down to nothing more than an assumption about players' strategies, which are fixed ex ante. In essence, they simply assumed the result they were trying to prove.

In fact, however, the holdout problem is really no different from the bilateral monopoly problem that occurs when a single seller faces a single buyer. As Robert Cooter pointed out long ago, theory and common sense both predict that parties will bluff, exaggerate, stall, hold out, and take other strategic measures to achievc a greater share of the surplus available from a successful bargain. Such measures are properly thought of as a kind of transaction cost, and there is no reason to think they are more likely as the number of parties increases. See Cooter, supra note 83, at 23. 
allow polluters to either pay damages or eliminate the pollution, whichever is cheaper.

TABLE 1

Optimal Legal Rules and Number of Parties

\begin{tabular}{|l|l|l|}
\hline & \multicolumn{1}{|c|}{ Few Parties } & \multicolumn{1}{c|}{ Many Parties } \\
\hline Theory & $\begin{array}{l}\text { Property rule (injunction): } \\
\text { enhance private bargaining }\end{array}$ & $\begin{array}{l}\text { Liability rule (damages): } \\
\text { private bargaining precluded } \\
\text { by high transaction costs }\end{array}$ \\
\hline Practice & $\begin{array}{l}\text { No bargaining after injunctions: } \\
\text { enmity (Farnsworth } \\
\text { bilateral monopoly }\end{array}$ & No holdouts: Cheshire \\
\hline bis
\end{tabular}

Empirical studies fail to bear out the prediction that bargaining should succeed when the number of parties is small, however. ${ }^{96}$ For example, Ward Farnsworth investigated twenty nuisance suits to learn if the parties bargained over the outcomes after a final disposition by the judge. ${ }^{97} \mathrm{He}$ selected the cases with an eye toward meeting the requirements for low transaction costs-small number of parties, only a single issue, and so on. ${ }^{98}$ He reported results completely at odds with the outcome he had expected based on theory: " $[\mathrm{N}]$ one of the parties in the twenty cases made trades after judgment. They generally did not negotiate at all after judgment. Nor did the lawyers in these cases think there would have been bargaining if the litigation had ended with a judgment in the opposite direction." 99

Thus, after Farnsworth's study, only one tenet of the theory of optimal legal rules in nuisance disputes remained largely unshaken: the prediction that liability rules should be employed in multiparty disputes. Indeed, Farnsworth's results indirectly lent additional credence to this prediction. For if parties do not bargain even when transaction costs are low, a fortiori, there is no reason to expect successful bargaining when transaction costs are high. The only study that seemed to point in the opposite direction was

94. Ward Farnsworth, Do Parties to Nuisance Cases Bargain After Judgment? A Glimpse Inside the Cathedral, 66 U. CHI. L. REv. 373 (1999).

95. The experimental evidence from Hoffman and Spitzer also suggests that holdouts are unlikely to arise in negotiations with as many as nineteen sellers. Hoffman \& Spitzer, supra note 91, at 150 .

96. See, e.g., Ellickson, supra note 8; John J. Donohue Ill, Diverting the Coasean River: Incentive Schemes to Reduce Unemployment Spells, 99 YALE L.J. 549 (1989).

97. Farnsworth, supra note 94 .

98. Id.

99. Id. at 384 (footnote omitted). Famsworth suggests that enmity or acrimony between the litigants eonstituted the major barrier to postlitigation negotiations. Id. Additionally, he attributes the lack of negotiations to parties' view that their claims were not translatable into eash. Id. 
a behavioral experiment conducted by Hoffman and Spitzer, who foundat least under laboratory conditions - that buyers were able to negotiate deals with up to nineteen sellers without encountering serious holdout problems. ${ }^{100}$ Yet no real-world study has ever substantiated their finding. On the contrary, several authors have written on the prevalence of holdouts, suggesting that the holdout problem is both serious and real. ${ }^{101}$

Our study of the Cheshire buyout is an attempt to bridge theory and practice. The Cheshire buyout suggests that conventional law and economics models go astray by failing to appreciate the significant effects of communities. In developing the theory of nuisance disputes, theorists have begun with a single polluter and a single victim and then, holding everything else (but transaction costs) equal, increased the number of victims. ${ }^{102}$ But this approach misses the essential jointness of decision making in environments characterized by strong interpersonal ties. We discuss the effect of this factor on standard theorizing in Part IV, infra. First, however, we must consider two alternatives that might explain the absence of holdouts while remaining consistent with traditional law and economics analysis.

III

\section{Background Legal Rules and Their Application to Cheshire}

Conventional law and economics theory offers two explanations for why none of the Cheshire residents decided to hold out and sue AEP. First, the residents may not have had a viable legal claim under Ohio nuisance law. ${ }^{103}$ Second, the expected value of holding out may have been less than the value of AEP's buyout offer. Only if ncither of these rationales explains the absence of holdouts is it necessary to look beyond the standard law and economics analysis.

100. Hoffman \& Spitzer, supra note 91, at 150.

101. See, e.g., Andrew Alpern \& Seymour Durst, Holdouts! (1984); Andrew Alpern \& Seymour Durst, New York's Architectural Holdouts (1984).

102. See, e.g., Polinsky, supra note 90.

103. Ohio law would have governed the residents' claims. Fortunately (for the purposes of this Article), Ohio nuisance law is nearly identical to the model both law and economics scholars and law professors use. For example, Ohio law recognizes causes of action for both private and public nuisance. See infra text accompanying notes 107-12, 122-26. Moreover, it permits pollution victims to bring a nuisance suit against regulated polluters. See infra text accompanying notes 114-15. Finally, and most important, it provides for both damages and injunctive relief. See infra text accompanying notes 13034. Therefore, any outcome predicted under Ohio law is generalizable to law and economics theory and to the many other states that elected not to follow New York in denying injunctive relief to pollution victims. See Boomer v. Atl. Cement Co., 257 N.E.2d 870 (N.Y. 1970); cf. Bell \& Parchomovsky, supra note 15 (discussing the effect of Boomer on the legal entitlement of the residents). 


\section{A. Ohio Nuisance Law}

Nuisance law constitutes an important intersection between property and torts. Despite its long history, ${ }^{104}$ or perhaps because of it, nuisance law has evolved into a "legal grab-bag that the courts seize[] upon as a substitute for analysis whenever they wish[] to redress an injury." 05 This judicial proclivity has made nuisance a top contender for the "mostimpenetrable-jungle-in-the-entire-law" award. ${ }^{106}$

\section{Cause of Action}

Nuisance law encompasses two distinct causes of action, private and public nuisance, which share very little other than their name. ${ }^{107}$ Private nuisance arises from the "invasion of another's interest in the private use and enjoyment of land." 108 Public nuisance arises from an invasion of a public right-for example, the obstruction of a public road. ${ }^{109}$ Ohio law

104. For an excellent historic review, see Jeff L. Lewin, Boomer and the American Law of Nuisance: Past, Present, and Future, 54 ALB. L. REv. 189, 192-96 (1990) (tracing the origin of private nuisance law back to the twelfth century).

105. Id. at 192; accord W. Page Keeton et al., Prosser and Keeton on the Law of Torts 549-50 (5th ed. 1984) ("It has meant all things to all people, and has been applied indiscriminately to everything from an alarming advertisement to a cockroach baked in a pie." (footnotes omitted)); William L. Prosser, Insurance Without Fault, 20 TEx. L. Rev. 399, 410 (1942) (dubbing nuisance a "legal garbage can").

106. KELTON ET AL., supra note 105, at 618 ("There is perhaps no more impenetrable jungle in the entire law than that which surrounds the word "nuisance.").

107. Because AEP has been operating in Cheshire for about three decades, if sued, AEP could raise a statute of limitations defense. With respect to public nuisance, the general rule in Ohio is that "no length of time can legalize a public nuisance." Little Miami R.R. Co. v. Comm'rs of Greene County, 31 Ohio St. 338, 349 (1877); accord 1540 Columbus Corp. v. Cuyahoga County, 589 N.E.2d 467,470 (Ohio Ct. App. 1990). As for private nuisance, the statute of limitations in Ohio is four years. See OHlo Rev. Code ANN. § 2305.09(D) (Anderson 2001).

Importantly, Ohio law divides private nuisance claims into two types, "permanent" and "continuing." In Olpp v. Hocking Valley Railway Co., 3 I Ohio Dec. 453 (Ct. C.P. 1920), the Court of Common Pleas defined a permanent nuisanee as one that continues indefinitely without change of charaeter, $i d$. at 468 , and a continuing nuisance as abatable by skill and labor, id. at 469 . For permanent nuisances, the statute of limitations begins to run "at the time that the nuisance begins or is first noticed, provided that the permanent nature of the nuisance ean be ascertained at that time." Brown v. County Comm'rs of Scioto County, 622 N.E.2d 1153, 1162 (Ohio Ct. App. 1993) (citing Miehael A. DiSabatino, Annotation, When Statute of Limitations Begins to Run as to Cause of Action for Nuisance Based on Air Pollution, 19 A.L.R. 4th 456, 459-60, § 2(a) (1983); Louisville Briek \& Tile Co. v. Calmelat, 6 Ohio Ct. App. 435 (Ct. App. 1917)). For continuing nuisance, an action "can be brought for damages for those injuries incurred within the [limitations period], regardless of when the nuisance began." Brown, 622 N.E.2d at 1162 . We believe that the air pollution produced by AEP should be classified as a continuing nuisance. First, the character of the emissions changed in 2001 after the installation of the SCRs, which caused the appearance of the blue plume. Second, there is ample evidence that AEP could take measures to abate the nuisance. Hence, a statute of limitations defense would not bar the residents' potential suits for either a public or a private nuisance.

108. Restatement (SECOND) OF Torts $\$ 821$ D (1979).

109. See, e.g., Donald G. Gifford, Public Nuisance as a Mass Products Liability Tort, 71 U. CIN. L. REv. 741, 833 (2003). 
provides causes of action for both private and public nuisance. ${ }^{110}$ To prevail in a private nuisance suit, "it is not necessary that [the residents] should be driven from their dwellings.... [I]t is enough that [the residents'] enjoyment of life and property is rendered uncomfortable, for in some circumstances discomfort and annoyance may constitute a nuisance." particular relevance to our case is Ohio's recognition of qualified nuisances that consist of "anything lawfully but so negligently or carelessly done or permitted as to create a potential and unreasonable risk of harm which, in due course, results in injury to another." 112

Under Ohio's qualified private nuisance claim, AEP's activities would still constitute a nuisance even if AEP was complying with all applicable air pollution regulations. ${ }^{113}$ An action for a qualified private nuisance "is essentially an action in tort for the negligent maintenance of a condition, which, of itself, creates an unreasonable risk of harm, ultimately resulting in injury."114 In Blankenship v. S.H. Bell Co., a case involving facts very similar to those of Cheshire, the court found a polluter liable even though "[it] was not formally found to have violated its permits." 115

The Cheshire residents thus had a strong prima facie case against AEP for maintenance of a qualified nuisance. ${ }^{116} \mathrm{~A}$ qualified private nuisance claim first requires a demonstration of substantial injury resulting in physical discomfort. There is substantial evidence that AEP caused such an injury. In January 2002, the Agency for Toxic Substances and Disease Registry reported that the levels of sulfur dioxide and sulfuric acid in

110. See Brown, 622 N.E.2d at 1158. In Rautsaw v. Clark, 488 N.E.2d 243 (Ohio Ct. App. 1985), the Ohio Court of Appeals further elucidated that the law of private nuisance "generally turns on the factual question[s] whether the use to which property is put is a reasonable use under the circumstances, and whether there is 'an appreciable, substantial, tangible injury resulting in actual, material, [and] physical discomfort." Id. at 245 (citations omitted) (quoting Antonik v. Chamberlain, 78 N.E.2d 752 (Ohio Ct. App. 1947)).

111. See Brown, 622 N.E.2d at 1161 (citing 61 AM. Jur. 2D Pollution Control § 531 (1981)).

112. Metzger v. Pa., Ohio, \& Detroit R.R. Co., 66 N.E.2d 203, 205 (Ohio 1946) (quoting Taylor v. Cincinnati, 55 N.E.2d 724, 732 (Ohio 1944)); see also Interstate Sash \& Door Co. v. Cleveland, 74 N.E.2d 239, 239 (Ohio 1947) ("As distinguished from a qualified nuisance involving negligence, . . . absolute liability attaches notwithstanding the absence of fault."); State ex rel. Schoener v. Bd. of County Comm'rs, 619 N.E.2d 2, 5 (Ohio Ct. App. 1992) ("Strict liability is imposed when an absolute nuisance is found to exist, but negligence must be proved to establish a qualified nuisance.").

113. Brown, 622 N.E.2d at 1160.

114. Id. (citing Allen Freight Lines, Inc. v. Consol. Rail Corp., 595 N.E.2d 855, 856 (Ohio 1992)). In Rothfuss v. Hamilton Masonic Temple, the Ohio Supreme Court held that "[i]n an action based on the maintenance of a qualified nuisance, the standard of care owed to one injured is that care a prudent man would exercise in preventing potentially or unreasonably dangerous conditions to exist." 297 N.E.2d 105, 109 (Ohio 1973).

115. No. 94 ClV 422, 1999 Ohio App. LEXIS 6418, at *8 (Ohio Ct. App. Dec. 22, 1999).

116. Others have reached the same conclusion; the lawyers representing the residents also believcd that they had a strong case, at least with rcspect to certain individuals. Hammond, supra note 47. 
Cheshire "pose[d] a public health hazard to some residents, particularly residents with asthma," and produced "adverse effects on the lungs."117 Furthermore, the blue plume emanating from AEP's plant had immediate adverse effects on the physical well-being of Cheshire residents, who experienced breathing problems, headaches, and eye soreness. ${ }^{118}$ In certain cases, the blue plume created sores and aggravated preexisting medical conditions. ${ }^{119}$ It also instilled fear of future injuries in many Cheshire residents.

Because the claim requires a demonstration of negligence along with injury resulting in physical discomfort, Cheshire residents also would have had to prove that the benefits to residents of pollution abatement outweighed the costs to AEP. Significantly, AEP admitted that it could abate the emissions of sulfur trioxide. ${ }^{120}$ Indeed, AEP repeatedly stated that it would take measures to do so. ${ }^{121}$ Given the documented environmental impact, the health effects, and the existence of cost-effective abatement measures, it appears that the residents had a fair chanee of prevailing in a private nuisance suit against AEP.

Cheshire residents' case in an action for a public nuisance seems equally strong, perhaps even stronger. ${ }^{122}$ Section 3745-15-07 of the Ohio Administrative Code prohibits the

emission or escape into the open air ... of smoke, ashes, dust, dirt, grime, acids, fumes, gases, vapors, odors, or any other substances or combinations of substances, in such manner or in such amounts as to endanger the health, safety or welfare of the public, or cause unreasonable injury or damage to property. ${ }^{123}$

\footnotetext{
117. Seelye, supra note 53, at Al (quoting the Agency's report).

118. See, e.g., Harrison 1, supra note 1.

119. Hammond, supra note 47.

120. See Press Release, American Electric Power, supra note 40.

121. Id.

122. The weight of authority suggests that an action for a public nuisance-like an action for a private one-requires a showing of either an absolute nuisance or a qualified nuisance. Thus, our analysis of qualified nuisance is equally applicable here. However, recently, in Hager v. Waste Technologies Industries, No. 2002-Ohio-3466, 2002 WL 1483913 (Ohio Ct. App. June 27, 2002), the Ohio Court of Appeals stated that

By enacting [Ohio Administrative Code $\S 3745-15-07]$, Ohio declared that the proscribed eonduct therein constituted an unreasonable interference with a public right ... to remain free from exposure to polluting substances that in such a manner or amount endanger the health, safety or welfare of the public, or which causes unreasonable injury to property .... [Such conduct] is found to be a public nuisance. Id. at *11.

123. OHIo Admin. Code $\S 3745-15-07$ (2003). 1t is also noteworthy that section 3704.05(A) of the Ohio Revised Code states that "[n]o person shall cause, permit, or allow emission of an air contaminant in violation of any rule adopted by the director of environmental protection." OHIO REv. CODE ANN. $\S 3704.05$ (A) (Anderson 2002).
} 
To bring a private action for a public nuisance, an individual resident or the Village of Cheshire as a whole would have to demonstrate a particular harm "of a different kind than that suffered by the public in general."124 In Brown v. County Commissioners of Scioto County, the Ohio Court of Appeals specifically stated that where a party "lost an opportunity to sell her property and was unable to use and enjoy it, [her harm is] sufficiently distinct or particular ... so as to allow recovery under a statutory nuisance theory." 25 Under this standard, the residents of Cheshire probably had standing to bring a private action for a public nuisance against AEP. ${ }^{126}$

Furthermore, the residents could have involved the EPA in their legal battle against the plant. The EPA was already closely following the problem, and pressure from the residents could have resulted in administrative action against the plant. ${ }^{127}$ Additionally, the residents could have tried to persuade the attorney general to bring a lawsuit for a statutory public nuisance against AEP, ${ }^{128}$ thereby substantially increasing the likelihood that residents would receive injunctive relief.

\section{Remedies}

But what remedy could the Cheshire residents obtain if they prevailed? Specifically, could the residents secure an injunction against AEP? In an action for either private or public nuisance, a plaintiff may seek damages or injunctive relief. ${ }^{129}$ As a rule, the standard remedy in an action for a

124. Brown v. County Comm'rs of Scioto County, 622 N.E.2d 1153, 1160 (Ohio Ct. App. 1993).

125. Id.

126. It should be noted that in Hager v. Waste Technology Industries, 2002-Ohio-3466, 2002 WL 1483913 (Ohio Ct. App. June 27, 2002), the Ohio Court of Appeals refused to overrule a summary judgment denying relief to neighboring property owners who brought an action for statutory public nuisance against a hazardous waste incineration facility. Critical to the court's decision was its finding that the property owners "produced no evidence, other than mere allegations, that any of the alleged pollutants or emissions endangered the health, safety, or welfare of the public." Id. at *14. Furthermore, the defendant adduced two expert testimonies attesting that "the alleged airborne pollutants and odors emanating from WTI [Waste Technologies Industries] were minimal or nonexistent." Id. at*16. In Cheshire, by contrast, it is quite clear that the emissions posed a danger to the health of the residents.

127. After the purchase was negotiated, Ohio regulators levied a $\$ 40,000$ fine against AEP "for allowing burned-coal waste, called fly ash, repeatedly to escape from the Gavin plant. Separately last month, federal regulators found the company violated the Clean Air Act by allowing high levels of tiny particles to repeatedly blow from the plant." Mary Beth Lane, Cheshire: Some Who Are Staying Won't Vote to Dissolve, Columbus DisP., Feb. 2, 2003, at D1.

128. The Ohio Revised Code provides that "[t]he attorney general, upon request of the [director of environmental protection], shall bring an action for an injunction, a civil penalty, or any other appropriate proceedings in any court of competent jurisdiction against any person violating or threatening to violate section $3704.05 \ldots$ of the Revised Code." OHIO REv. CODE ANN. $\$ 3704.06$ (B) (Anderson 2002).

The Cheshire residents we spoke to were highly skeptical about the political will of state regulators to act against AEP. In their view, Cheshire was in a politically disenfranchised part of Ohio and AEP was a major force in Ohio politics. They believed they had little or no chance of getting regulators to intervene on their side in this dispute. Hammond, supra note 47; Harrison II, supra note 35.

129. See generally Jesse Dukeminier \& James E. KrIER, Property 755 -59 (3d ed. 1993). 
private nuisance is monetary damages; a court would grant an injunction only if damages could not adequately redress the injury. ${ }^{130}$ If a claim for damages is sustained, "the measure of damages is not the decrease in value of the fee but the impaired value of the use of the premises."

Courts award equitable relief only if the injury is irreparable. ${ }^{132}$ Thus, if a nuisance causes only property damage, injunctive relief is unlikely. When a nuisance also affects health and comfort, however, the analysis changes, and courts are more willing to enjoin the harmful activity. ${ }^{133}$ Actual personal injury is not a prerequisite for an injunction. Substantial annoyance or physical discomfort that do not amount to an actual injury may also warrant injunctive relief. ${ }^{134}$ Furthermore, in the case of continuing nuisances, Ohio law generally allows plaintiffs to proceed in equity to relieve them of the burden of having to bring a new suit for damages every several years. $^{135}$

Given that courts have broad discretion in deciding whether to grant injunctive relief, it is difficult to predict with accuracy how the residents would have fared. However, unlike in Boomer, an injunction probably would have required only that AEP abate the pollution rather than close the plant. As explained below, AEP could have implemented at least three

130. See, e.g., Adams v. Gorrell, 161 N.E. 786, 787 (Ohio Ct. App. 1927) ("If one so uses his property as to injure the rights of another, he is liable in damages to the person so wronged, and, if the damages are not adequate, and the injuries cannot be fully compensated in money, a court of equity will intervene by way of injunction and grant appropriate relief.").

131. Frey v. Queen City Paper Co., 66 N.E.2d 252, 254 (Ohio Ct. App. 1946). One measure of the "impaired value of the premiscs" is the depreciation in rental value or the cost of repairs. Id.

132. Irreparable harm is an injury for which no plain, adequate, and complete remedy exists in law. See Harden Chevrolet Co. v. Pickaway Grain Co., 194 N.E.2d 177 (Ohio Ct. C.P. 1961); see also Olpp v. Hocking Valley Ry. Co., 31 Ohio Dec. 453, 472 (Ct. C.P. 1920) ("By the term irreparable injury it is not meant that there must not be any physical injury or possibility of repairing the injury. All that is meant is that the injury would be a grievous one, at least a material one, and not adequately reparable in damages.").

Douglas Laycock has argucd that despite this kind of rhetoric, plaintiffs can often secure an injunction without proving an "irreparable injury," because courts have watered down the meaning of that phrase:

A wide range of wrongs relating to land are regularly hcld to inflict irreparable injury. These include ... nuisance [and many other wrongs]. Courts offer a variety of explanations for why the injury is irreparable in these cases[, . . but] [w]hatever the rationale, injunctive relief is almost never withheld in these cases on the ground that damages are an adequate remedy.... [However,] it is sometimes withheld on other grounds, especially the disproportionate expense of removing an encroachment or abating nuisance.

LAYCOCK, supra note 22, at 38 (footnotes omitted).

133. For example, in McClung v. North Bend Coal, 6 Ohio Cir. Dec. 243, 261 (Cir. Ct. 1895), the court granted the plaintiff injunctive relief, finding that smoke and noxious gases emitted by the defendant's coal operations had seriously and injuriously affected the plaintiff's health.

134. Dale v. Bryant, 141 N.E.2d 504, 507 (Ohio Ct. C.P. 1947) (citing Eller v. Koehler, 67 N.E. 89 (Ohio 1903)).

135. See discussion supra note 107. 
measures, at varying costs, to abate the pollution. The mere existence of these alternatives strengthens the case for injunctive relief. A court also would likely have given weight to the fact that the town itself and many of its residents were there before the plant was built, and long before the pollution problem started. ${ }^{136}$

Despite the findings of Douglas Laycock's comprehensive studywhich showed that prevailing plaintiffs typically get the remedy they seek $^{137}$-obtaining an injunction is not a foregone conclusion. In light of the modern judicial proclivity against injunctions, one should not overestimate the likelihood of obtaining such relief. ${ }^{138}$ However, even under a strict standard, the residents would have had a nonnegligible chance of securing injunctive relief if they had chosen to litigate. Moreover, even a credible threat to sue could have improved residents' bargaining position because such a lawsuit likely would have adversely affected AEP's reputation, a situation the company probably would have been eager to avoid.

And yet, not a single resident chose to take AEP to court.

\section{B. Expected Rational Behavior Under Traditional Economic Analysis}

The Cheshire buyout deal was susceptible to two kinds of holdouts. First, each resident could refuse to deal and instead could bring an action for a nuisance against AEP, seeking to enjoin the pollution. We refer to this possibility as the "pollution holdout." Second, because AEP was planning to expand its operation, the company needed to construct a new dock on at Ieast some of the properties heId by Cheshire residents. ${ }^{139}$ The affected residents were therefore in a position to block the expansion plan by refusing to sell. We refer to this strategy as the "expansion holdout."

\section{The Pollution Holdout}

For any resident in a pollution dispute, the issue is not whether she can hold out but rather which action produces the greatest payoff in monetary and nonmonetary terms. Because the issuance of an injunction is a probabilistic event, and the payoff is also uncertain, it can be difficult for

136. On the principle of "first in time" in property, see DUKEMINIER \& KRIER, supra note 129, at 3, 14-15, 24.

137. See LAYCOCK, supra note 22, at vii ("Plaintiffs usually get the remedies they seek, because courts usually find that other remedies are inadequate.").

138. See John P. Dwyer \& Peter S. Menell, Property Law and Policy: A Comparative Institutional PERspective 316 (1998) ("Courts today rarely grant prohibitory injunctions for nuisance on the simple theory that the plaintiff is entitled to prohibit an invasion of his property rights.").

139. Properties along the banks of the Ohio River were necessary for dock expansion. In addition, AEP presumably needed storage space for the incoming coal and access to the riverfront land. Hence, the company probably needed to acquire additional land for its planned expansion. 
victims of pollution to choose between settlement and litigation. The case of Cheshire is illustrative. One can create high- and low-end estimates of a resident's expected return from refusing to sell and instead seeking an injunction against AEP. The point of this exercise is to approximate the thought process of pollution victims who must decide, under real-world conditions, which course of action to pursue. The numbers are perforce highly imprecise and should be used only to give a rough, back-of-theenvelope measure of the orders of magnitude involved.

As just shown, Ohio's nuisance law might have allowed the residents of Cheshire to obtain an injunction against AEP. What are the possible implications of this finding? Let's assume the probability of an injunction actually issuing was between $30 \%$ and $60 \%$. An injunction that issued probably would order AEP to abate the nuisance without specifying a particular method for achieving this outcome. AEP would rationally attempt the least costly means of abatement first. The least costly means would most likely be the magnesium-calcium injections described earlier, ${ }^{140}$ with an estimated cost of between $\$ 14$ and \$21 million. ${ }^{141}$ This technology has some finite chance of substantially eliminating the nuisance (estimated to be between $70 \%$ and $90 \%$ ). Assuming the first remedy failed, AEP probably could eliminate most or all of the blue plume by switching to lowsulfur coal, thereby reducing its sulfur trioxide emissions. This alternative might cost between $\$ 100$ and $\$ 200$ million, with an $80 \%$ to $95 \%$ chance of successfully eliminating the nuisance. Finally, if all else failed, AEP could shut down the plant, the value of which is roughly $\$ 2$ to $\$ 3$ billion. Table 2 summarizes these estimates and a calculation of the value to the residents of securing an injunction.

\footnotetext{
140. See Press Release, American Electric Power, supra note 45, and text accompanying note 49 .

141. Whether the cost of the technical solution is properly viewed as an advantage of securing an injunction is not straightforward. AEP had apparently promised to clean up the sulfur trioxide emissions (using this technical solution) even before it agreed to purchase the Cheshire properties. Hence, an injunction securing the right to "force" AEP to do something that it was arguably going to do without the injunction would be worth nothing to a Cheshire resident. On the other hand, if the only reason for AEP's announcement that it would clean up the pollution was fear of litigation by the residents, then the company might have decided not to install the cleanup technology once most of the town agreed to sell. In that case, the right to force AEP to install this technology would be valuable to any holdouts who obtained this right. If we assume that AEP would have installed the new technology to comply with EPA regulations regardless of the outcome of the buyout, the gains from holding out drop from $\$ 10.2$ to $\$ 6$ million.
} 
TABLE 2

EXPECTED BENEFIT OF REFUSING TO SELL AND

SEEKING AN INJUNCTION

(Dollar Figures Are in Millions)

\begin{tabular}{|c|c|c|}
\hline & Low & High \\
\hline Probability of an injunction being granted & 0.3 & 0.6 \\
\hline Cost of new technology & $\$ 14$ & $\$ 21$ \\
\hline Probability new technology will not solve the problem & 0.1 & 0.3 \\
\hline Additional cost of using clean coal & $\$ 100$ & $\$ 200$ \\
\hline Probability clean coal will not solve the problem & 0.05 & 0.2 \\
\hline Plant's shutdown value & $\$ 2,000$ & $\$ 3,000$ \\
\hline Gross expected benefit of obtaining an injunction ${ }^{142}$ & $\$ 10.2$ & $\$ 156.6$ \\
\hline $\begin{array}{l}\text { Plus expected health damages (waived in case of } \\
\text { settlement) }\end{array}$ & $\$ 0.1$ & $\$ 0.5$ \\
\hline Less legal fees of $30 \%$ & $\$ 8.5$ & $\$ 129.2$ \\
\hline Net present value & $\$ 5.9$ & $\$ 90.5$ \\
\hline
\end{tabular}

Under these assumptions, the gross expected value of refusing to sell and obtaining an injunction ranges from $\$ 10.2$ to $\$ 156.6$ million. ${ }^{143}$ As noted earlier, the lower estimate could be substantially smaller than $\$ 10.2$ million if the odds of obtaining an injunction were significantly lower, or if AEP would have installed the cleanup technology even without the threat of litigation by the residents.

Health care costs are another piece of the settlement estimate. As part of the buyout, the residents agreed to waive their future rights to sue for health injury related to the plant's pollution. Estimating the probability and cost of health problems is complex. That said, all current indications suggest that there is a relatively low chance of serious injury from the

142. For purposes of this table, let $p=$ probability of an injunction being granted, $C N T=\operatorname{cost}$ of new technology, $q=$ probability new technology will not solve the problem, $C C=$ additional cost of using clean coal, $r=$ probability clean coal will not solve the problem, $S V=$ shutdown value, $G E B=$ gross expected benefit of obtaining an injunction, then $G E B=p[C N T+q(C C+r S V)]$.

143. Under our assumptions, the shutdown value of the plant has relatively little influence on the final valuc of holding out because it is so unlikely that a shutdown would be necessary. Even if the shutdown value were zero, it would only reduce the gross expected benefit to between $\$ 7.2$ and $\$ 48.6$ million.

The estimated likelihood of obtaining an injunction strongly affects the overall valuation. If the chance of a successful injunction were only $10 \%$, it would lower the gross value to $\$ 3.4$ million, which is still an order of magnitude larger than the sums individual residents actually received. 
exposure so far, so a reasonable estimate is that the expected damages might range from $\$ 100,000$ to $\$ 500,000 .{ }^{144}$

Even after deducting $30 \%$ to cover legal fees and allowing for the time value of money, ${ }^{145}$ the expected gain to a resident from litigating against AEP is still substantial-in the range of $\$ 6$ to $\$ 90$ million. Not included in this calculation are any gains the residents might be able to extract from the adverse publicity that a nuisance suit would cause AEP. In addition, if the residents were to prevail, their victory could precipitate similar lawsuits against AEP in other locales. Moreover, a reputation as an insensitive polluter could damage AEP politically, subjecting it to closer regulatory scrutiny. ${ }^{146}$ The potential damage to AEP's reputation weakens AEP's bargaining position, thus increasing residents' incentive to pursue an injunction.

\section{The Expansion Holdout}

In explaining the Cheshire buyout, AEP insisted that it was in no way related to fear of liability. ${ }^{147}$ Instead, the company consistently argued that the purpose of the deal was to secure necessary land for the construction of an expanded coal-unloading facility, which would alleviate a bottleneck in the plant's operation. Assuming that AEP was not bluffing, some residents - most likely those with riverfront property - were clearly in a position to block the deal by refusing to sell their property. As is the case with all instances of coordinated development, each resident could refuse to convey his fee simple to AEP, and any attempt to take the properties nonconsensually would be enjoined by trespass.

Notably, AEP never disclosed how many properties it needed to acquire to construct the dock, which hindered any resident's ability to predict the extent of her holdout power. Residents' inability to determine the credibility of AEP's plan to build the dock further eroded the company's potential holdout problem. Furthermore, holding out with respect to the dock plan, even if credible, creates a different threat point than winning an injunction in a pollution suit. Blocking the construction of the new dock

144. Many residents are elderly and therefore would probably die before they experienced any negative effects.

145. Suppose litigation over nuisance liability, and the granting of an injunction, took four years combined. At an annual interest rate of $5 \%$, the present value of the $\$ 8.5$ million would shrink to about $\$ 5.9$ million.

146. Of course, the reputational argument runs both ways. AEP's decision to deal with the residents runs the risk of suggesting the company is a "soft touch," potentially subjecting the company to threats of litigation from residents near its other facilities. AEP's characterization of the settlement as a deal to purchase land for the expansion of the plant, rather than a settlement of a nuisance dispute, may be designed to forestall such a reputational risk. By couching the transaction as a unique, sitespecific purchase, the company undermined the ability of potential litigants to rely on the Cheshire precedent.

147. See, e.g., Teather, supra note 46. 
would have given the residents the ability to negotiate over additional profits AEP stood to gain from the expected reduction in operation costs, but would not have affected the company's existing operation. Because AEP never disclosed how much money it anticipated saving by building the new dock, it is impossible to put a value on residents' ability to prevent AEP from carrying out its plan.

\section{Summary}

How did all this affect the residents' decision to sell? Clearly, significant intangibles were at stake in litigating the Cheshire pollution dispute. Some of the uncertainties are so substantial that any attempt to assign dollar values to various outcomes and then arrive at an overall expected value to the plaintiffs is hopeless. Yet even on a very conservative (prodefendant) calculation, a successful litigant stood to collect millions of dollars.

Based on the expected payout from litigation described above, one would assume some Cheshire residents would have found the gains from suing were high enough to justify a refusal to sell on AEP's terms. But no one did. Thus, it remains a puzzle why among the 220 residents of Cheshire, not a single person concluded that litigating was preferable to accepting AEP's offer. ${ }^{148}$ It is the task of the remainder of this Article to explain why the residents left so much money on the table and to explore the implications of this case for legal policy and economic theory.

\section{IV}

\section{EXPlaining the ABSENCE of Holdouts}

If standard law and economics analysis does not explain the failure of Cheshire residents to bring a lawsuit against AEP, other factors must have been decisive. This section incorporates into the analysis various nonlegal factors that shaped the behavior of the parties. As will become clear, none of these factors is particular to Cheshire; they have widespread applicability in pollution disputes. The incorporation of these factors leads to results considerably different from those predicted by law and economics models. The empirical approach utilized here reveals that the role of law is much more limited than is commonly assumed and that to the extent law is relevant it is for reasons not commonly addressed by standard theory. ${ }^{149}$

148. A handful of residents refused to sell to AEP. Although these residents had various reasons for refusing to sell, none indicated an intention to seek a higher payoff by suing AEP or by blocking construction of the dock. Thus, the few owners who refused to deal are not really holdouts because they lack the critical strategic motivation. Rather, as we explain in greater detail in Part V, infra, they are better termed "holdins," who place an extraordinarily high subjective value on their continued presence in Cheshire.

149. One possible explanation for the buyout that we do not discuss but that we cannot completely rule out is that the residents decided to sell based on the legal advice they received. Specifically, the residents' lawyers may have preferred to collect the attorney fecs provided to them under the buyout 


\section{A. Ignorance of the Law}

One possible explanation of Cheshire residents' failure to bring a lawsuit against AEP is simply that they were uninformed about the law. In his classic study of land use disputes in Shasta County, California, Robert Ellickson found that residents rarely resorted to legal action because of the high cost of learning legal rules, as well as a preference for resolving disputes extralegally, even when the parties knew the rules. ${ }^{150}$ Although Cheshire is also a rural community, the cost of learning the law likely played no role in residents' decision not to sue. On the contrary, the stakes here were high enough so that both AEP and the residents of Cheshire obtained legal representation, and lawyers played a key role in the eventual buyout agreement. Nevertheless, Ellickson's work is instructive in that it highlights the importance of viewing things from the perspective of affected parties.

\section{B. Social Norms}

In attempting to explain the absence of holdouts in Cheshire, one of the first factors that comes to mind is social norms. Many studies have established the potential of social norms to coordinate behavior, especially in small communities such as Cheshire. The works of Ellickson, ${ }^{151}$ Lisa Bernstein, ${ }^{152}$ Richard McAdams, ${ }^{153}$ Elinor Ostrom, ${ }^{154}$ and Eric Posner, ${ }^{155}$ among others, repeatedly demonstrate the ability of close-knit groups to prevent individual members from acting strategically and to encourage them to act instead in a way that maximizes group welfare. Cheshire was a close-knit community with strong interpersonal ties among its residents, thus satisfying some preconditions for the formation of social norms.

Although social norms may have curbed to some extent the incentive to hold out, they were not on their own responsible for the outcome in

agreement, a reported $\$ 4.5$ million, rather than litigate and face the uncertainty of trial. All our attempts to investigate this possibility by interviewing the residents failed, and the lawyers refused to talk to us about the substance of the case. We stress that we have no information supporting this theory, but it remains a possibility.

150. ElLICKSON, supra note 8, at 123-36. The irrelevance of law parallels Ellickson's findings from Shasta County, albeit for different reasons. In Shasta County, law was largely irrelevant because it was supplanted by social norms and because the cost of learning the law was too high. Id. In Cheshire, people seemed aware of their legal rights but could not make use of them because extralegal factors superseded them. It is important to note, moreover, that the disputes Ellickson chronicled in Shasta County took place among community insiders; in Cheshire, the dispute was essentially between the community and an outsider-the AEP's Gavin Plant.

151. Id.

152. See Bernstein, supra note 16.

153. See Richard H. McAdams, The Origin, Development, and Regulation of Norms, $96 \mathrm{MiCH}$. L. Rev. 338 (1997); Richard H. McAdams, Comment, Accounting for Norms, 1997 Wis. L. Rev. 625.

154. See, e.g., Elinor Ostrom, Collective Action and the Evolution of Social Norms, 14 J. EcoN. Persp. 137 (2000).

155. See generally Eric A. Posner, Social Norms (2000). 
Cheshire. The social norms story runs into two separate problems. First, social norms are most effective when repeated interaction among group members is expected. ${ }^{156}$ When they are likely to encounter each other again, individual members have an incentive to abide by the social norms because the long-term benefits they derive from the community exceed the immediate gains they can get from deviation. ${ }^{157}$ Social norms are enforced through a "tit-for-tat" mechanism, under which present deviations will be punished in similar transactions in the future. Obviously, none of these conditions obtain in the Cheshire case, because the dispute with AEP was a onetime occurrence, and, if successful, the buyout would dissolve the village. Second, the buyout offer did not require unanimous consent from the residents but only simple majority approval. Although AEP might have relied on social pressure to forge the requisite majority, such pressure cannot adequately explain the decision of almost all the residents to agree to the buyout.

Consequently, social norms are not a plausible explanation for the absence of holdouts in Cheshire. More generally, this analysis casts doubt on the ability of social norms to prevent holdouts in dissolving communities. The more plausible explanation for the cooperative behavior in Cheshire lies in the interdependence among individual residents in closeknit communities created by the amenities that such communities provide. Thus, although norms per se are not responsible for the end result, the focus on social interaction highlighted in the norms literature provides a helpful reference point for the following analysis.

\section{The Realities of Nuisance}

The cut-and-dried discussions of nuisance disputes in classrooms and stylized articles fail to capture the essence of nuisance situations. The legal focus of the discussions blinds readers to nonlegal factors that regulate the behavior of parties to a much greater extent than the law does. In this section, we highlight two factors relevant to Cheshire residents in their decision whether to hold out: the harsh reality of living with pollution and the reputational stakes for the company.

\section{Living Near a Polluter}

Unlike other torts, pollution, as a continuous tort, has a daily effect on residents. This factor dramatically diminishes the viability of litigation as a solution for pollution victims, especially those with children. The constant fear and inconvenience Cheshire residents experienced made them largely indifferent to how much they could get by holding out. The case of Ron Hammond is representative. A high school teacher, Ron moved to Cheshire

156. Robert Axelrod, The Evolution of Cooperation 12-14 (1984)

157. See generally Michael TAYLOR, COMMUNiTy, ANARCHY AND LiBERTY 65-90 (1982) 
in 1985 when he was still single. He later married and started a family. Ron's oldest daughter suffers from severe asthma. Although Ron does not blame AEP for his daughter's medical condition, he does attest that AEP's pollution made his daughter's life, and that of the family as a whole, virtually unbearable. The pollution aggravated his daughter's preexisting condition, and on several occasions she required hospitalization. To minimize their daughter's exposure to pollution, the Hammonds took extreme precautions. Every day they checked the sulfur dioxide monitor at the town hall, and, when the pollution count was high, they did not let their daughter play outside. To allow their daughter to ride her bike, the Hammonds were forced to travel twenty miles each way. Every day was a challenge. ${ }^{158}$

For the Hammonds, exhausting the course of litigation was not an option; their goal was to leave Cheshire as soon as possible. As Ron Hammond statcd, "I would leave yesterday, if I could."159 But the Hammonds' only asset was their property, and their property was worthless because of the pollution. ${ }^{160}$ The pollution placed the Hammonds in a terrible bind: it simultaneously provided them with a strong incentive to leave and deprived them of the ability to do so. The Hammonds made it clear to everyone that they would leave at the first opportunity. For them, the buyout offer could not have come soon enough. Their concern for their children's health trumped any monetary consideration. Ron firmly believes that their continued stay in Cheshire adversely affected the long-term health of his children. Holding out in the hope of receiving more money from AEP was an inconceivable strategy.

Other residents with children echoed the sentiment. Jennifer Harrison stated that on certain days when the blue plume blanketed the town, her children, who were perfectly healthy, suffered from debilitating headaches and respiratory difficulties. She too strove to find a way to get her children out of Cheshire. ${ }^{161}$ Indeed, it is hard to think of a parent who would risk the future of her children in exchange for a larger amount of money. The children's health factor therefore played a much greater role in the decisionmaking process of the residents than did the rights and powers the law afforded them. No standard discount rate could capture the time value for the residents. To residents with children, the potential cost of staying was simply prohibitive. But leaving was also difficult or impossible. The residents faced a real-world liquidity constraint that theoretic models of nuisance disputes conveniently overlook.

158. Hammond, supra note 47

159. Id.

160. In theory, it might have been possible for the Hammonds to move out and rent their property to someone else. However, this solution was essentially foreclosed by the thin market for properties in Cheshire, which vanished altogether after the blue plume began to appear in 2001 .

161. Harrison 11, supra note 35. 
Other residents who could not afford to wait, but for a different reason, were Cheshire's elderly residents. They were concerned that they would not live to see the outcome of the litigation. Residents revealed to us that their lawyers estimated that the litigation process, with all the appeals, could take ten years. For many of the residents in their seventies and eighties, litigation was a dubious prospect, the benefits of which they would never reap.

The length and cost of litigation made law largely irrelevant for some residents of Cheshire. Conversely, these factors gave substantial leverage to AEP in negotiating a buyout deal in the (relatively short) shadow of the law and the (much longer) shadow of its stacks, for at least a portion of the town.

\section{Reputational Stakes}

Another factor that seems to have played a more important role than law did in the Cheshire story was media coverage. Indeed, the media were instrumental in leveling the playing field. The residents realized AEP's sensitivity to reputational harm relatively early in their struggle. Originally, AEP's operations were causing not only pollution but also excessive noise. After residents' complaints fell on deaf ears, the residents decided to bring their grievances to the local press. The effect of the media exposure on AEP was immediate; it corrected the noise problem right away. However, by so doing, it betrayed a weak spot for negative media coverage. ${ }^{162}$

The residents took full advantage of this Achilles' heel. They were able to interest the Columbus Dispatch in their struggle, and the result was a series of articles entitled "Cheshire-Death of a Village." 163 The newspaper even volunteered to conduct a laboratory test, at its own expense, to determine whether the soil in the village was contaminated. Furthermore, the town invited Mary Beth Lane, a Dispatch reporter, to spend a month in Cheshire. She accepted the invitation.

AEP's two-pronged reaction demonstrates its sensitivity to negative media coverage. First, it tried to demonstrate to journalists that it was making a sincere effort to curb the problem. For example, during Mary Beth Lane's sojourn in Cheshire, AEP apparently started experimenting with clean, low-sulfur coal-an experiment the company discontinued after the journalist's departure. ${ }^{164}$ Second, and simultaneously, AEP, whose headquarters are located in Columbus, attempted to discredit the Dispatch's coverage in the Ohio business community. For example, according to Mary Beth Lane, "[t]he company has voiced its concern, from time to time, about

162. Id.

163. The capital of Ohio, Columbus, is located about two hours' drive from Cheshire; the Dispatch is the region's most important newspaper.

164. Harrison 11 , supra note 35 . 
the number of stories we have published about Cheshire and the tone of the stories. AEP [thought] the newspaper ha[d] gone overboard on the coverage." 165 And Ben Marrison, the editor of the Dispatch, told us that "[AEP] has tried to chide us for our coverage, making remarks about our coverage being excessive, and calling the [']Dispatch['] the 'Cheshire Dispatch." 166 Of course, the Dispatch was not the only media outlet interested in the Cheshire story. The blue plume attracted considerable attention from national and international news media after AEP made the buyout offer. $^{167}$

Media involvement provided a strong inducement to AEP to bring closure to the Cheshire problem as soon as possible. The bad press seems to have been a thorn in AEP's side. It is quite possible, as some residents suggested, that AEP considered the amount paid to residents to be "shut-up" money. ${ }^{168}$ The press's continuous interest in Cheshire helped offset the time factor-that is, residents' desire to leave Cheshire quickly because of the pollution - that favored AEP.

The discussion to this point has explained why some residents were reluctant to hold out and has explored AEP's motivation to settle. However, for a full view of what happened in Cheshire it is imperative to consider another, more important factor-community externalities-a subject to which we turn next.

\section{Community Externalities}

Although the problem of living with pollution explains why some residents were reluctant to hold out, it does not explain why no resident did so. To get a full understanding of what happened in Cheshire, we must consider community externalities.

A community provides certain benefits for individuals that they would not otherwise be able to enjoy. ${ }^{169}$ One set of benefits consists of amenities such as schools, parks, police and health services, and even stores. Some are classic public goods, whereas others, such as schools and stores, may be provided privately but cannot exist without sufficient demand to cover

165. Email from Mary Beth Lane, Reporter, Columbus Dispatch, to the authors (Feb. 12, 2003) (on file with authors).

166. Email from Ben Marrison, Editor, Columbus Dispatch, to the authors (Feb.12, 2003) (on file with authors).

167. See, e.g., ABC Nightly News (ABC television broadcast, May 13, 2002) (airing a report by Barry Serafin entitled "Residents of Cheshire, Ohio Move out of Their Polluted Town"); On the Record (FOX News television broadcast, May 13, 2002) (airing an interview by Greta Van Susteren with Cheshire resident Ron Hammond and AEP spokesman Pat Hemlepp); Seelye, supra note 53.

168. Harrison 11 , supra note 35 .

169. See generally Hanoch Dagan \& Michael A. Heller, The Liberal Commons, 110 YALE L.J. $549,572-79$ (2001) (discussing the social and economic effects stemming from communities). 
their fixed costs of operation. ${ }^{170} \mathrm{~A}$ second important set of benefits that communities provide stems from the social interactions that they themselves make possible. Ties of friendship are goods most people value highly and actively seek out. Such interpersonal networks often arise from physical proximity and commonality of interest over long stretches of time. ${ }^{171}$ Because of these benefits, each resident in a community has a stake in the continued presence of other members and simultaneously bestows a benefit on others by his own presence.

Communities give rise to externalities because each individual member does not take account of the benefits she provides to others in the community when deciding whether to depart. Alan Ehrenhalt's description of the parish of St. Nicholas of Tolentine on Chicago's southwest side during the 1950 s provides an example of how such externalities arise. ${ }^{172}$ Part of the way residents participated in community life was by sitting out on their stoops and chatting, gossiping, and watching each other. Ehrenhalt's account makes clear that each resident valued such interactions very highly. With the advent of television, however, residents tended to withdraw from their stoops to their living rooms, where their solitary activities did nothing to foster the community. This withdrawal does not indicate that residents placed no value on community but rather that they failed to take account of the externalities inherent in supporting community by neglecting the impact of their own withdrawal on their neighbors. By withdrawing from the community to watch television in private, each resident not only increased his own consumption possibilities but also diminished those available to his fellow residents, an effect of which residents are unlikely to take full account. One might term this lack of consideration for one's influence on the community the John Donne effect. ${ }^{173}$ The Donne effect played a significant role in Cheshire, for reasons we now explore.

170. There are actually two large bodies of literature on the economics of cities. The older literature views the city as a kind of common property regime and stresses the divergence between average and marginal congestion costs (and benefits), which can lead to inefficiencies. See, e.g., George S. Tolley, The Welfare Economics of City Bigness, I J. URB. EcoN. 324 (1974). The newer economic geography literature uses increasing returns and (positive) spillovers to explain the growth of cities. See, e.g., Paul Krugman, Increasing Returns and Economic Geography, 99 J. PoL. EcoN. 483 (1991). Edward Glaeser and others have also written about the importance of social networks or community ties in cities. See, e.g., Edward L. Glaeser, The Future of Urban Research: Nonmarket Interactions, I BROOKINGS-WhARTON PAPERS ON URB. AFF. 101 (2000).

171. For examples of powerful evocations of the strength and vitality of such communities, see Ehrenhalt, supra note 17; ERIKson, supra note 17. Robert Putnam's Bowling Alone, supra note 17, offers a mass of quantitative evidencc for the decline of community in the United States after the late $1950 \mathrm{~s}$.

172. EHRENHALT, supra note 17, at 90-95.

173. Donne wrote: "No man is an island entire of itself; every man is a piece of the Continent, a part of the main." John DonNe, Devotions upon EMERGENT OCCASIONS, meditation 17 (1624). 


\section{Fixed Costs, Availability, and Community Size}

Most goods and services cannot be produced without incurring some fixed costs. These setup costs introduce a "lumpiness" or indivisibility in the availability of many commodities. Setting up a restaurant, gas station, or grocery store requires expenditures that do not depend on the number of customers served. Hence, such operations cannot be scaled down to an arbitrarily small size, because without enough customers they cannot cover their fixed costs or operate at a profit. Given these fixed costs, and an inability to serve those who live outside a limited geographic boundary, the availability of goods and services at a particular locale depends on the population size and density. Therefore, it is not surprising that there is no French restaurant in Fergus Falls, Minnesota, or classical radio station in Ketchikan, Alaska; the local population with the requisite tastes is not large enough to cover the fixed costs of these activities. ${ }^{174}$

Individuals who live in the same geographic market therefore confer a positive externality on each other: each helps defray the fixed costs of providing goods or services that they all value. The magnitude of these community externalities varies with community size. The larger the community is, the smaller the marginal effect each member has on the welfare of others.

The application to Cheshire is straightforward. As a town of 220 people, it was big enough to support a gas station, a coffee shop, and two churches. But if the town were to get much smaller, many of these institutions would be unlikely to survive. When a substantial chunk of the population appeared ready to leave, therefore, those who might have been tempted to remain would certainly realize that the shrunken town could not sustain many of these amenities, not to mention police or fire services or a school.

In deciding whether to hold out in an effort to seek better terms from the buyer, Cheshire residents had to consider the possibility that, if they did so, they might be deprived of the basic social infrastructure that made them want to stay in Cheshire. Refusing to sell a studio apartment in Manhattan is quite different from remaining as the only resident in a ghost town. And the possibility of being Cheshire's sole citizen was very real. In short, the high cost of remaining in a town stripped of most of its amenities by the

174. Waldfogel calls the requirement of a sufficient number of residents to support a particular service a "preference externality." See Joel Waldfogel, Preference Externalities: An Empirical Study of Who Benefits Whom in Differentiated Product Markets, 34 RaND J. ECON. (2003). In the case of goods that virtually everyone values-for example, groceries and gasoline-the extemality depends only on the size of the community, not on the tastes of its individual members. For examples of the unraveling of communities caused by the loss of economies of scale when some residents left, see Peter $T$. Kilborn, Mississippi Floods Drain Life from River Towns, N.Y. TIMES, Aug. 16, 2002, at A15 (describing a gradual erosion of the business community in Winfield, Missouri, after residents started to decamp). 
departure of many of its residents may have been a major reason for the absence of holdouts.

\section{Friendships and Community Networks}

Beyond the joint defrayal of fixed costs in providing essential amenities, a second, and perhaps more important, set of externalities stems from the closeness of small communities and the resulting interpersonal ties that develop. Reeent economic scholarship has suggested that friendships are a form of "social capital."175 Such social capital complements market interaction by allowing actors to achieve mutually beneficial results, even when contracting is impossible. Based on his study of Italy, Robert Putnam has argued that communities characterized by close relationships of trust do better than those in which members act atomistically. ${ }^{176}$ The presence of community may be especially important for the poor, who rely on it as a form of insurance or risk sharing. ${ }^{177}$

A complementary, and more compelling, characterization of friendships is that they are simply ends in their own right, independent of their economic consequences. In either case, residents who are part of communities that foster such friendships often value them highly and experience loss and alienation if they are destroyed. ${ }^{178}$

Almost every Cheshire resident willing to speak to reporters emphasized the closeness of the community. ${ }^{179}$ To be sure, not everyone harbored

175. See Glenn C. Loury, A Dynamic Theory of Racial Income Differences, in WomeN, Minorities, And Employment Discrimination 153 (Phyllis A. Wallace \& Annette M. LaMond eds., 1977). For a critical assessment of this term, see Steven N. Durlauf, The Case "Against" Social Capital, 20 Focus 1, 1 (1999).

176. PUTNAM, supra note 16.

177. As Brion noted:

Especially among the poor, the existence of a matrix of mutually shared values and ... concern and support is a necessary condition, not just to psychic well-being, but to physical survival itself. ... The poor must often depend on a web of mutual support ... with each individual contributing to the others whatever ... special talents he might have. When [such] exchanges exist, they can ... reinforce [each other], creating a milieu the value of which far exceeds what the physical reality might suggest. When this milieu is destroyed and its members scattered, it is irretrievably lost.

Denis J. Brion, The Meaning of the City: Urban Redevelopment and the Loss of Community, 25 IND. L. REv. 685, 702 (1991).

178. In addition to the sources cited already, consider the description of unsuccessful efforts to rebuild towns in the floodplain of the Mississippi River after they were destroyed in the flood of 1993. See Kilborn, supra note I 74.

179. We are not trained ethnographers, and we were unable to make an extcnded visit to the town or talk to a comprehensive cross section of the population. We recognize the possibility that residentsor the newspaper reporters who covered the story-may have had good reason to exaggerate the depth and breadth of sentimental attachment to the town. Moreover, those willing to speak out could have been disproportionately nostalgic or satisfied with things as they were. Nevertheless, we believe the evidence of strong communal ties is compelling, especially because many residents had lived in the town for many years; several families could trace their ancestry in the town back several generations. 
a sentimental attachment to the town. ${ }^{180}$ But at least a substantial group did. Jennifer Harrison, the town clerk and a supporter of the buyout, may have put it best when she told us that before the buyout plan, the community had been very close, "like Mayberry." 181 Despite her support for the deal, she expressed disappointment that the residents were all going to scatter when the plan went through. ${ }^{182}$

A poem written several decades ago by village resident Helen Preston articulates the same feelings. It begins: "The little town of Cheshire where I live is very, very small. / But it's home with precious happy memories to us one and all." In an interview, Preston, age eighty-eight, revealed that her family has lived in the immediate area for more than two hundred years; an ancestor was born near Cheshire in I800. Several generations of her family are buried in the local cemetery, which is named for her great-grandfather Benjamin McCarty and occupies the former site of the family's farm near town. Preston's sense of connection with the past is palpable. "Family history lives on in [her] living room as well, where she keeps photographs, souvenirs and yellowed newspaper clippings in a large suitcase next to her favorite armchair. She has a saying: "If the house ever gets afire, grab that suitcase." "183

In another interview, Preston noted:

I'm between the devil and the deep blue sea.... All my friends and neighbors are here and we'll be scattered like ducks. I'm not able to just pick up 50 years worth of plunder and furniture and move... . This little village has been my whole life. If a majority sells, I don't want to just sit here in the coal yard ... . I reckon my best bet is to get out. ${ }^{184}$

180. To some residents, "the crux of the deal is money: With the giant smokestacks, coal piles and conveyor belts looming over Cheshire, their property values are shot. They're thrilled with what they see as a once-in-a-lifetime chance to unload their homes for at least twice the assessed values." Simon, supra note 36 , at Al.

181. Harrison I, supra note 1.

I 82. Id. Another villager, Mary Fulton, grew up with her grandmother and great-grandmother as neighbors. She chose another fictional analog for Cheshire-Grover's Corner, New Hampshire-and remarked that "[I]ife used to be simple here. .. . 'It was like Our Town." Buckley, supra note 28, at IA. To be fair, one newspaper reporter said of Cheshire "It's country, but it's hardly Mayberry. Not everyone knows everyone else. They lock their doors at night." Id. On the other hand, an Ohio reporter observed that "[ $t]$ here are perhaps too many trailers in back yards for it to be picturesque, but it's wellkept and homey. It's ... the kind of place where residents keep their doors unlocked and know the names of every dog in town." James F. Sweeney, Town for Sale, Cleveland Plain Dealer, June 9, 2002, at LI.

183. Mary Beth Lane, Precious Memories, Columbus DisP., July 7, 2002, at $\mathrm{Cl}$.

I84. Tim Jones, Electric Plant Finally Overtakes Small Ohio Town, CHI. TRIB., Aug. 11, 2002, at Al. Other Cheshirites describe a deep emotional attachment not just to the people of the town but to the site itself and its scenic location on the banks of the Ohio River. "It becomes a part of you, and you become attached to it ... I I think, as opposed to blood, I have Ohio River water coursing through my veins."' Price, supra note 59, at Bl (quoting Cheshire resident Elizabeth Bailey). 
Another indication of the strength of the community comes, paradoxically, from the animosity that developed in the wake of the decision to sell. Some residents blamed those who engineered or supported the deal, even though many in the latter group did so only reluctantly. This animosity suggests that at least some sellers felt coerced into selling and agreed not because they valued their property at less than the price offered by AEP, but because they stood to lose both the value of their home and the value of their community ties if they refused.

For example, Jeannie Elkins Mollohan, a forty-one-year-old grocery store worker,

attended the local high school, River Valley High, and [was] trying to organise [sic] a 25-year reunion for the class of 1978 . "This is a sad end for the town," she said. "I have a co-worker in his 50s who lived there all his life with his mother and now they have to pull up their roots. What else can they do? It's a tragic situation and for the people affected I can see a righteous anger." 185

One early advocate of the sell-off found that his daughters "suffered relentless teasing [at school]: 'Can I shake your hand?' classmates would say. 'I've never shaken the hand of a millionaire before.' No one sat near the family at high school football games."186 At one game, someone called the father "Judas." 187 Gladys Rife, another longtime resident, commented to a reporter, "Honey, listen, this deal has caused more problems. . . Friend against friend, neighbor against neighbor, family against family. So many hard feelings. I'm praying it doesn't go through." "188 In another example of life imitating art, Gladys Rife was interviewed after "switch[ing] off an 'Andy Griffith Show' rerun with a snort of disgust. 'Cheshire is nothing like that [anymore],' she says, gesturing to the TV screen." 189 These reactions suggest that even with generous compensation, many residents believed they were coming out behind by selling. In other words, they may have felt that AEP was undercompensating them for the loss of their community. ${ }^{190}$

Interpersonal networks are costly to create and maintain, and much of their value is not transferable to other locations. In that sense, friendships resemble an investment in firm-specific human capital. ${ }^{191}$ Thus, interpersonal ties are an asset that is bound to lose some of its value with

185. Teather, supra note 46, at 3 (quoting Cheshire resident Jeannie Elkins Mollohan)

186. Buckley, supra note 28.

187. Id.

188. Simon, supra note 36 , at Al.

189. Id.

190. The residents' motivations were complex, and no single characterization can do justice to them. For example, some who opposed the sale may have felt they were losing out relative to other sellers, rather than bcing opposed to the sale per se.

191. Gary Becker, Human Capital (3d ed. 1993). 
dramatic changes in the makeup of communities. The profound interdependence that exists in small, close-knit communities is responsible for their cohesiveness and stability; it was certainly a hallmark of Cheshire. But paradoxically the very cohesiveness of such communities may lead to problems of undercompensation when the communities dissolve.

\section{Community Externalities and Individual Decision Making}

Interdependencies among individuals have long been known to affect individual decision making. Perhaps the most famous example of this effect is Thomas Schelling's explanation for dynamic resegregation in the housing market. ${ }^{192}$ In Schelling's tipping model, the exit of the least tolerant White property owners upon the entry of minority residents reduces the attractiveness of the neighborhood for the remaining White residents and precipitates their departure. ${ }^{193}$ Although Schelling worked on a different problem, his analysis is illuminating in that it highlights the impact of one's neighbors on one's own welfare in close communities and captures a dynamic that also seems to account for the result in Cheshire.

The outcome in Cheshire may also be explained, in part, by analogy to coercive tenders in corporate law. In a series of articles in the $1980 \mathrm{~s}$, Lucian Bebchuk outlined the coercive effects of tender offers. ${ }^{194}$ As Bebchuk's analysis reveals, interdependencies among shareholders allow for the possibility that a carefully designed purchase offer may make it rational for some owners to sell their shares at prices below what they believe the shares are worth. ${ }^{195}$ This coercion occurs because the offer to buy immediately, explicitly or implicitly, contains a threat not to buy at all, or to buy only at a lower price in the future. ${ }^{196}$ The discount on future purchases forces shareholders to choose between tendering their shares at

192. See Thomas C. SChelling, Micromotives and Macrobehavior 140-55 (1978); Thomas C. Schelling, A Process of Residential Segregation: Neighborhood Tipping, in RaCIal Discrimination IN ECONOMIC Life 157 (Anthony H. Pascal ed., 1972); Thomas C. Schelling, Dynamic Models of Segregation, 1 J. MATH. Soc. 143, 167-71 (1971).

193. For critical discussion of Schelling's theory, see Abraham Bell \& Gideon Parchomovsky, The Integration Game, 100 CoLum. L. REv. 1965, $1985-89$ (2000) (delineating the limits of Schelling's tipping model).

194. See Lucian Arye Bebchuk, The Pressure to Tender: An Analysis and a Proposed Remedy, 12 Del. J. CORP. L. 911 (1987) [hereinafter Bebchuk, Pressure to Tender]; Lucian Arye Bebchuk, Toward Undistorted Choice and Equal Treatment in Corporate Takeovers, 98 HARv. L. REv. 1695 (1985) [hereinafter Bebchuk, Undistorted Choice]; Lucian Arye Bebchuk, Comment, The Case for Facilitating Competing Tender Offers, 95 HARV. L. REV. 1028 (1982). Numerous others have noted these coercive effects as well. See, e.g., Edward F. Greene \& James J. Junewicz, A Reappraisal of Current Regulation of Mergers and Acquisitions, 132 U. PA. L. REv. 647 (1984); Michael C. Jensen \& Richard S. Ruback, The Market for Corporate Control: The Scientific Evidence, 11 J. FIN. Econ. 5 (1983); Louis Lowenstein, Pruning Deadwood in Hostile Takeovers: A Proposal for Legislation, 83 Colum. L. REv. 249 (1983); Elliot J. Weiss, Defensive Responses to Tender Offers and the Williams Act's Prohibition Against Manipulation, 35 VAND. L. REv. 1087 (1982).

195. Bebchuk, Undistorted Choice, supra note 194, at 1696.

196. Id. 
the "front-end" price specified in the offer or waiting and facing a lower, "back-end" price if the takeover succeeds. ${ }^{197}$ So long as the front-end price is higher than the back-end price, a shareholder who believes that a tender offer will succeed is best advised to sell immediately. ${ }^{198}$

Empirical studies indeed verify that the front-end share price specified in tender offers generally exceeds the market share price both prior to the announcement of the proposed takeover and subsequent to its successful completion. ${ }^{199}$ That is, the front-end price is usually the best price available for a share, unless another suitor presents an offer superior to the initial offer. Thus, even if a shareholder believes that the "true" value of the share is greater than the front-end price of the share, he will tender his shares, so long as he believes that the tender offer is likely to succeed. As several commentators have noted, the tender offer places shareholders in the familiar position of players in a prisoner's dilemma, in which they are compelled to act against their own best interests. ${ }^{200}$

The analogy to communal buyouts is relatively straightforward. The same group dynamics that prompt shareholders to tender their shares involuntarily may also spur members of small communities to sell their properties to a polluter. The fear of being left at the back end, with the attendant adverse consequences, and the difficulty of coordinating a collective response may cause property owners to accept offers they would otherwise reject. Analogizing to the corporate context, then, polluters should be able to buy small towns at a price lower than the aggregate value their residents assign to them.

197. Id.

198. Id.

199. See studies discussed in Bebchuk, Pressure to Tender, supra note 194; David W. Leebron, Games Corporations Play: A Theory of Tender Offers, 61 N.Y.U. L. REv. 153 (1986); see also J. Gregory Sidak \& Susan E. Woodward, Takeover Premiums, Appraisal Rights and the Price Elasticity of a Firm's Publicly Traded Stock, 25 GA. L. Rev. 783 (1991).

200. See, e.g., Bebchuk, Pressure to Tender, supra note 194; John C. Coffee Jr. \& William A Klein, Bondholder Coercion: The Problem of Constrained Choice in Debt Tender Offers and Recapitalizations, 58 U. CHI. L. Rev. 1207 (1991); Jeffrey N. Gordon, Ties That Bond: Dual Class Common Stock and the Problem of Shareholder Choice, 76 CALIF. L. REv. 3 (1988); Robert A. Prentice, Front-End Loaded, Two-Tiered Tender Offers: An Examination of the Counterproductive Effects of a Mighty Offensive Weapon, 39 CASE W. RES. L. REv. 389 (1989).

There is much dispute about why front-end prices should be higher than back-end or pre-tenderoffer prices. Clearly, the raider believes that the shares are undervalued at market price, perhaps because she believes that the market price does not sufficiently reflect the available information concerning the target corporation's prospects for future earnings. Or it may be because the raider believes that if she is able to take control of the corporation, she will be able to introduce superior management or synergy, and thereby improve the target corporation's profitability. Or the raider may intend to use eontrol of the corporation illicitly to divert corporate profits away from the corporation (and thereby away from the minority owners) to herself. For our purposes, the motives of the raider are irrelevant. It is important only to note that the price differential between the front-end and back-end prices pressures shareholders to tender. 
A simple numeric example illustrates the point. Assume that Tinytown is a small community with two hundred residents, each of whom owns an identical house with a market value of $\$ 100,000$. All residents also value the close nature of their community, but they vary in their valuation of this attribute: half value it at $\$ 20,000$ and half at $\$ 80,000$. Hence, the total value of Tinytown to its residents is $\$ 30$ million. Assume now that Pacific Cement wishes to open a new plant in the vicinity of Tinytown. The expected value of the new plant to Pacific is $\$ 25$ million. However, the plant will cause pollution that will render the residents' properties worthless. Rather than litigating, Pacific can offer to buy each resident's property for $\$ 125,000$. Even though the offered price is considerably lower than the subjective valuation of half of the community members, all will agree to sell. The low-value owners will sell because the offer price exceeds the value they place on their continued residence in Tinytown. The high-value owners will sell because they realize that oncc the low-value neighbors depart, the community that they value at $\$ 80,000$ will also vanish. ${ }^{201}$ of course, this result is undesirable from an efficiency standpoint because the value of the town to the residents as an ongoing entity exceeded its value to the polluter.

In reality, additional factors may enhance residents' incentive to sell at a discount. First, the distribution of values may be more variable and may vary with the size of the community. Our example included only two groups of owners, who placed high and low values on the community. In reality, one should expect to find a continuum of valuations. This variation in valuations should make it easier for a buyer to unravel the community by picking off those most willing to leave. Second, the residents will have to make the decision to sell under conditions of uncertainty about the valuations of their neighbors. These valuations are private information that may be neither observed nor verified. In many pollution settings, there is no real market for the affected properties, and the polluter is effectively a

201. True, they may still bring a lawsuit against Pacific Cement, but all they will be able to recover now, if they win, is the market value of the property-that is, one hundred thousand dollars. One might argue that the high-value owners could offer a Coasean "bribe" to the low-value owners to induce them not to sell. In the scenario described in the text, a payment from the high-value owners to the low-value owners of seven thousand dollars in exchange for not selling would leave both sets of residents better off. Such a bribe is unlikely to work, however, for at least two reasons. First, the offer of money necessarily undermines the very existence of the asset that is being "acquired"-that is, friendship. Norms of friendship, by definition, are inconsistent with the monetization of community that this bargain requires. See, e.g., John J. Donohue I11, Prohibiting Sex Discrimination in the Workplace: An Economic Perspective, 56 U. CH1. L. Rev. 1337, 1352 \& n.44 (1989) (arguing that "the very act of paying a bribe [to undo sex discrimination by an employer] will undermine the self-esteem [of workers who have to pay the bribe. Hence,] there are some Coasean bribes that are intrinsically incapable of achieving their goal."). Second, even setting this obvious problem aside and approaching the matter from a purely economic perspective, such transfer payments are difficult to negotiate unless each side knows the other's true valuation and the low-value owners can credibly commit not to sell if the payment is made. 
monopsony, so coresidents lack any objective valuation measures. ${ }^{202}$ In Cheshire, for example, there had been no real estate transactions in the several years preceding the buyout offer. Finally, given that litigation is costly, that its outcome is uncertain, and that home owners are risk averse, ${ }^{203}$ many will be inclined to sell to the polluter-even at a steep discount-rather than sue for damages.

Statements made by Cheshire residents provide some support for this analysis. Scott Lucas, a seventy-year-old former mayor of Cheshire, commented: "[I] realize that even if there isn't any pollution, it sure looks like there is ... . [I] would have been happy to stay here. ... The danger is, if you don't sell [to the plant], your house probably won't be worth a dime." 204 The story of the Macks echoes these sentiments. Married for sixty-three years, Harold and Odella Mack, ages eighty-four and eightytwo, lived in Cheshire their entire lives. Both belonged to the Cheshire Baptist Church for that entire period, and Harold, also a former mayor of Cheshire, helped incorporate the village in 1953. They explained that their decision to leave was not due to any health risks "but because everyone else was pulling up stakes." 205

An interview with one of the two owners who decided to stay confirms the theory that many residents sold to AEP because they feared the consequences of remaining behind while others sold. The interviewee spoke of a "great fear factor," especially among older residents. He said that people were afraid to find themselves living in a "ghost town" if they did not sell. ${ }^{206}$ Several things AEP did contributed to residents' fear. First, AEP gave departing owners salvage rights. ${ }^{207}$ By permitting residents to gut their houses, the salvage provision increased the likelihood that the residences would forever remain uninhabitable. It also raised concerns about exposure to asbestos and other hazards for those who remained. ${ }^{208}$ Second, Jennifer Harrison pointed out to us that it was rumored that AEP was planning to turn the entire town into a coal heap. ${ }^{209}$ In combination,

202. A monopsony is defined as a "situation in which one buyer controls the market." BLACK's LAW Dictionary 1023 ( 7 th ed. 1996).

203. See, e.g., Justin Hughes, The Philosophy of Intellectual Property, 77 Geo. L.J. 287, 290 (1988) ("Within a single lifetime, property tends to make the property owner more risk-averse."); William K. Jones, Confiscation: A Rationale of the Law of Takings, 24 Hofstra L. Rev. 1, 6 (1995) ("Owners of property are typically risk-averse.").

204. Simon, supra note 36 , at A1.

205. Buckley, supra note 28 , at $1 \mathrm{~A}$.

206. Interview with Cheshire resident requesting anonymity, in Cheshire, Ohio (Feb. 10, 2003) [hereinafter Anonymous Interview]

207. Harrison II, supra note 35

208. Anonymous Interview, supra note 206.

209. Harrison II, supra note 35 . 
these developments made it all the more attractive to sell to AEP and bid Cheshire good-bye. ${ }^{210}$

Our theory finds further support in the structure of the buyout offer. AEP did not require the unanimous consent of Cheshire property holders. Rather, it required a simple majority of residents to sell for the deal to move forward. At first, the simple majority requirement seems puzzling because it allowed many property owners to remain in place and sue AEP in nuisance if they so chose. However, once we take into account community externalities, AEP's strategy makes perfect sense. AEP's insistence on acceptance by a simple majority virtually guaranteed that the community would "tip out," sending a signal to residents that selling was their only real option. ${ }^{211}$ Cheshire, and virtually any community of its size, could not remain viable after losing half of its members. It is true that, in principle, AEP did not have to include any majority requirement. The fear of being left at the back end should have prompted most, if not all, residents to sell. Yet requiring majority approval as a precondition for the buyout served as an additional antiholdout measure, providing further assurance that the deal would go through.

What dynamic resegregation, corporate takeovers, and Cheshire have in common is the existence of interdependencies among asset holders that markets cannot fully capture. The specific interdependency at work in Cheshire was that A's decision to sell her house influenced the value $B$ placed on his house. A's decision affects not only her own welfare but also

210. Id. Reccnt testimony, albeit from those who refused to sell, supports our contention that at least some who sold did so out of fear. Gladys Rife, age 81, was offered a substantial sum for her land, but refused to sell (although she did take AEP's offer of a life estate). She believes that "the residents were pushed into the deal because of fears that they would not be able to sell thcir homes because of the power plant, and by greed." Jamcs Doran, Town Takeover Is Blocked by Widows' Might, TIMES (London), Nov. 17. 2003, at 13 (describing Ms. Rife's views). She commented that " $[t]$ his whole thing is crazy. We got shafted. . . People were given no time to think about it. They took their money like idiots. Now a lot of them are sorry and thcy want to come back. But they can't."' Id.

Testimony from Beula Hern (another life estate holder) confirms this view. Interviewed on National Public Radio, Ms. Hern commented that

[W] hen we [the town] started this it wasn't to sell. It was to clean up their [AEP's] act. We wasn't asking them to buy us out. We were told that if we didn't sell our property, that we wouldn't get anything out of it because this plant had destroyed the value of our property. That's why people sold. And now there's a lot of people that's moved now that's very unhappy. Said they'd like to be back. They wish they'd stuck with me. And l've asked them, 'Why did you sell?' Said, 'Well, was afraid not to,' said, 'because they painted such a dark picture.'

Bula [sic] Hern Discusses Keeping Her Home in What's Now the Ghost Town of Cheshire, Ohio (National Public Radio broadcast, Nov. 15, 2003) [hereinafter Hern Interview].

211. AEP might have been able to get a better deal by offering to buy only half of the property at a premium over the fair market value--say, from the first forty-five residents who agreed to sell. This approach likely would have been cven more coercive to residents and probably would have enabled AEP to acquire the remaining properties at a discount from their market price. However, this strategy might have backfired, leading either to bad publicity for AEP or to increased enmity on the part of those residents who did not get the premium, which in turn could have increased the likelihood of litigation. See Farnsworth, supra note 94. 
that of all members of the relevant community. In sum, A's action generates an externality that other members of the community must bear. It is important to note in addition the temporal dimension of the problem. Those who sell early get to cash out at an attractive price, whereas those who stay end up with an asset that has been substantially devalued. Reasoning backward, rational asset holders should see little choice but to get out immediately rather than wait for the inevitable decline to occur. Naturally, the sell-fast strategy plays into the hands of potential acquirers-be they blockbusters, corporate raiders, or industrial polluters-who can then buy assets for less than their true value.

Social scientists have repeatedly noted the ability of small communities, by virtue of their cohesiveness, to overcome problems of free riding in the provision of collective amenities such as irrigation systems, roads, and other local public goods. The closeness and cohesion of small communities enable a lifestyle that is unavailable elsewhere and that residents may view as a premium offered by these locales. Paradoxically, the same cohesiveness and close interpersonal ties render members of small communities particularly vulnerable to the threat of buyouts and exercises of eminent domain. ${ }^{212}$ Potential takers can exploit the existence of community externalities to acquire assets on the cheap, even when doing so is unfair and possibly even inefficient. Correspondingly, members of small communities stand to be seriously undercompensated when their communities unravel, even when they consensually agree to sell.

The case of Cheshire has several normative implications for legal theory and policy. The three areas we discuss are tort theory, collective action theory, and takings theory. We will show that, in all three areas, Cheshire suggests some important refinements and policy changes. The lessons of Cheshire warrant close attention because, in the aftermath of the Cheshire buyout, several other communities are weighing the options of reaching similar deals with polluters. ${ }^{213}$ Thus, the normative discussion provided in this Article may guide the behavior of polluters and residents in future deals.

\section{$\mathrm{V}$ \\ IMPLICATIONS FOR TORT THEORY}

The standard analysis of pollution disputes posits a binary menu of remedies consisting of damages and injunctive relief. The academic literature treats the choice of remedy as the exclusive dominion of the court, over which parties exert no influence. ${ }^{214}$ Indeed, the project of law and

212. We discuss eminent domain in Part VIl, infra.

213. See examples cited supra note 11.

214. See, e.g., Richard R.W. Brooks, The Relative Burden of Determining Property Rules and Liability Rules: Broken Elevators in the Cathedral, 97 Nw. U. L. REv. 267, 267 (2002) (pointing out 
economics scholars has been to instruct courts on how to choose the optimal remedy. ${ }^{215}$ On this view, the polluter's and the residents' actions cannot affect a court's choice of remedy. ${ }^{216}$ However, this view misses a key feature of the law of remedies that may work to the advantage of polluters - the internal hierarchy between damages and injunctions. A basic maxim in the law of remedies is that injunctive relief is a residual remedy to which courts should resort only when damages cannot adequately redress the plaintiff's harm. As a dissenting Supreme Court Justice stated in Bowen v. Massachusetts, "even though a plaintiff often prefers a judicial order preventing a harmful act or omission before it occurs, damages after the fact are considered an 'adequate remedy' in all but the most extraordinary cases."217

In other words, the judicial determination of remedies involves a twostep process. First, the court must decide whether monetary damages adequately redress the wrong. Second, if the court decides that damages are inadequate in a particular case, it will grant the plaintiff injunctive relief. ${ }^{218}$ As we will show, polluters (and other private "takers") can take advantage

that of the various tasks facing the courts, "none is more important than choosing how to protect the rights and entitlements of the parties who appear before them").

215. See, e.g., Ian Ayres \& Eric Talley, Solomonic Bargaining: Dividing a Legal Entitlement to Facilitate Coasean Trade, 104 YALE L.J. 1027 (1995); Calabresi \& Melamed, supra note 10; Louis Kaplow \& Steven Shavell, Property Rules Versus Liability Rules: An Economic Analysis, 109 Harv. L. REv. 713 (1996); James E. Krier \& Stewart J. Schwab, Essay, Property Rules and Liability Rules: The Cathedral in Another Light, 70 N.Y.U. L. REv. 440 (1995).

216. One might argue that because courts take into account the respective loss to each of the litigants, and hence will consider the polluter's profits, the polluter actually affects the court's decision by determining the size and profitability of its operations. This inference is unwarranted for two reasons. First, it is not the size of the polluter, or even its profitability, that matters, but rather the cost of abatement. See A. Mitchell Polinsky, An Introduction to LaW and Economics 15-26 (2d ed. 1989). The misplaced focus on size, we suspect, stems from the notoriety of the decision in Boomer $v$. Atlantic Cement Co., 257 N.E.2d 870 (N.Y. 1970), in which the court compared the value of the cement plant's operation to the harm to the residents. Boomer, however, is unrepresentative; in Boomer, the polluter allegedly had no way to abate other than to shut down the plant. The situation is different in most other cases, as our analysis of Cheshire demonstrates. See discussion supra Part III.A.2. Second, the forces of supply and demand determine the polluter's size and profitability. In other words, the market-not the probability of an injunction in a future lawsuit-determines how much polluters earn.

217. 487 U.S. 879, 925 (1988) (Scalia, J., dissenting). Various state courts historically have treated injunctions in a similar manner. See, e.g., Amdor v. Cooney, 43 N.W.2d 136, 140 (lowa 1950) ("[I]njunctions are granted sparingly, with caution and only in clear cases."); Cline v. Franklin Pork, Inc., 361 N.W.2d 566, 568 (Neb. 1985) ("An injunction against a nuisance is an extraordinary remedial process which is granted not as a matter of right but in the exercise of the sound discretion of the court, to be determined on consideration of all the circumstanccs of each case."); Aldridge v. Saxey, 409 P.2d 184,189 (Or. 1965) ("It is everywhere held that equity jurisdiction to enjoin an alleged nuisance is exercised sparingly and cautiously... ."). But see LAYCOCK, supra note 22, at vii (suggesting that plaintiffs are usually successful in getting the remedy they seek).

218. As a general rule, polluters will always favor damages over injunctions. A damage award deprives the residents of compensation for subjective value and eliminates their ability to hold out. The shift from injunctive relief to damages led Judge Jasen, dissenting in Boomer, to caution that the remedy ordered by the majority givcs private parties the power of eminent domain. Boomer, 257 N.E. 2d at 876-77 (Jasen, J., dissenting). 
of this two-step process to diminish the likelihood of an injunction being issued against them. As explained above, the fear of being left at the back end could spur a substantial percentage of residents of small communities to accept a buyout, even if the proposed price is below their subjective value of their property. Thus, regardless of a court's determination, a polluter will be able to buy out some percentage of a town.

Some owners who place particularly high subjective value on their property likely will refuse to sell. The reasons for the refusal may be ideological or pragmatic. Some owners may turn the deal down out of anger at the polluter. ${ }^{219}$ Others may find the price offered to them too low. A group that should be especially reluctant to sell is elderly residents. Elderly people who have lived in the same residence for decades may have an especially strong psychological and emotional attachment to their homes, and hence their subjective value may be well in excess of the market value of their property. In addition, the costs of moving and starting afresh in a new place are likely to be inordinately high for members of this group. Yet elderly owners are not the only ones who may refuse to deal. Residents with a preference for seclusion and isolation or who embrace an antipollution ideology may elect to remain in their homes even after a community unravels. Finally, residents who do not value community as highly as other residents may prefer to stay and sue the polluter in the hope of obtaining an injunction, which they can later parlay into a better bargain than their peers received. Such persons are willing to incur short-term losses in exchange for greater long-term gains. Their refusal to deal is strategic, and accordingly they are "holdouts."

Residents from any of these groups, particularly the potential holdouts, present a problem for polluters who are willing to engage in a buyout. For if residents who do not go along with a buyout may sue and get an injunction, the buyout deal no longer makes sense for the polluter. Any individual plaintiff who obtains an injunction can extract the lion's share of the bargaining surplus from the polluter, and ideological holdouts may refuse to sell back the injunction altogether. Why, then, would polluters engage in buyout negotiations? Or, in the context of Cheshire, why did AEP decide to move forward with the deal even though a handful of residents announced they were not going to sell and indeed acted as promised?

The answer to this question likely inheres in the judicial practice of denying injunctive relief when damages provide adequate compensation. This practice means that a favorable response to a buyout offer from the

219. For a discussion of whether policy makers should consider enmity in fashioning legal remedies, compare Ward Farnsworth, The Economics of Enmity, 69 U. CHI. L. REv. 211, 211 (2002) (arguing that generally courts should disregard enmity in deciding legal remedies) with Eric A. Posner, Law and Emotions, 89 GEo. L.J. 1977, 2006-10 (2001) (proposing that courts deny propcrty rule protection when enmity taints plaintiffs' relationships with defendants). 
majority of the affected residents dramatically reduces, if not eliminates, the ability of those who refuse to sign on to get an injunction. That the majority of residents agreed to take money as compensation for the pollution provides evidence that no injunctive relief is necessary to correct the harm. The higher the share of owners who have agreed to sell, the smaller the probability that those who refuse to sell will get an injunction. ${ }^{220}$ Given that injunctive relief is an equitable remedy granted at the court's discretion, it is highly unlikely that a court would empower $1 \%$ of property owners to enjoin the operation of the polluter if the remaining $99 \%$ went along with the buyout. Injunction in this situation is especially unlikely in light of the modern trend to award injunctive relief parsimoniously in nuisance cases. $^{221}$

If this analysis is correct, the dependence of injunctions on the adequacy of damages should discourage and in all likelihood eliminate strategic holdouts. Residents who decide not to sell and decide to sue instead may in the end get the same amount of money their former neighbors received by agreeing to the buyout. But the recalcitrant residents will get it at a much higher cost; they will have incurred the costs of litigation. Therefore, the buyout price set by the polluter, with some minor adjustments, will become the "damage award" the polluter will end up paying to all affected residents - those who sell immediately and those who take their grievance to court. Thus, by making a buyout offer that will be acceptable to the average property owner, the polluter effectively purchases immunity against holdouts - and against litigation in general. The buyout mechanism allows the polluter both to set the parameters of the legal relationship with residents and to exert control over the judicial election of remedies. Or, put differently, the use of buyout mechanisms enables polluters to "endogenize" injunctions. 222

The upshot of our discussion is that buyout mechanisms may clear the way to private takings. Formally, only the government may take private property without the owner's consent, and it may do so only if it pays the owner just compensation. ${ }^{223}$ Private actors are not endowed with a similar power; as against these "takers," a property rule protects an owner's fee

220. The desire to take an injunction off the table might explain the $50 \%$ requirement posted by AEP. Acceptance by a simple majority is probably the bare minimum necessary to show that a legal remedy is adequate under the circumstances. A lower acceptance rate would be meaningless for AEP, making it better for AEP not to have dealt at all. The simple majority requirement therefore served as a safety valve that enabled AEP to annul the bargain if it failed to achieve sufficient support among Cheshire residents.

221. See Lewin, supra note 104, at 198 (describing the erosion of injunctive relief as the paradigmatic remedy in nuisance suits).

222. By "endogenizing" injunctions, we mean influencing the probability of injunctive relief being granted. The probability does not drop to zero, however; courts still retain equitable discretion over the decision.

223. U.S. CoNST, amend. V. 
simple interest. In practice, however, private actors may force property owners to sell their property for a price lower than their own private valuations by making a buyout offer to members of the relevant community. As demonstrated, the risk of being left at the "back end," without community amenities and without interpersonal networks, is likely to force property owners to surrender their interests in exchange for the price offered by the private taker. As long as the polluter's offer is above market value, a majority of owners in the relevant community will agree to tender their titles. As explained, moreover, the majority's decision to accept the buyout offer will likely dramatically diminish the minority's probability of securing injunctive relief against the polluter. The interdependence among community members is not merely practical but also legal, and it acts to deprive certain property owners of the power to sell at a price of their choice, changing the nature of the protection of their right from a property to a liability rule.

The explanation for the absence of holdouts also explains the presence of "holdins"-residents who chose to remain in Cheshire after the buyout but who did not initiate litigation against AEP. The term "holdout" connotes a strategic motivation. A holdout's refusal to deal is grounded in the desire to extract as high economic rents as possible from the other party to the transaction. To succeed, a holdout must be in possession of a unique asset and must be able to determine the price of that asset. In other words, holdouts critically depend on property rule protection. Classic holdout settings involve indivisible projects, such as the construction of a new interstate highway for which the federal government must acquire all the properties along the planned course. In such a case, any single owner can block the entire project by refusing to sell. Nuisance cases are different because the nuisance causer does not have to acquire title to all affected properties to continue its operations. Once the threat of an injunction disappears, a polluter can pay damages and continue to carry out its activities. Absent the ability to get an injunction, pollution victims cannot hold out.

At present, however, the term "holdout" is attached to any person who refuses to deal for whatever reason. This colloquial use fails to capture the essence of the phenomenon, a strategic attempt to extract rents. Not all property owners who refuse to deal fit this description. In Cheshire, for instance, a handful of elderly residents rejected AEP's buyout offer for various reasons. Some placed a high subjective value on their continued stay in Cheshire. Their decision to stay was not motivated by a desire to do better than their neighbors who chose to sell. In fact, some may not have sold for any price. It is rumored that Jay Hall, who lives just outside of Cheshire but has property within the town limits, told several people that "AEP just can't pay enough to buy me out."

No effort to extract a better offer from the buyer accompanied these residents' refusal to sell. And, indeed, the preceding analysis of the law of 
remedies suggests that they would fail to enjoin AEP even if they were to try. Therefore, actors with high subjective valuations are not holdouts and should not be treated as such. Instead, owners who attach high idiosyncratic value should be termed "holdins." Whether the law should treat holdouts and holdins in the same way is a difficult question left for another occasion.

The categories of holdouts and holdins can over time shade into one another. The stories of the two resident owners who decided to stay provide an interesting illustration of this possibility. Beula "Boots" Hern, an eighty-two-year-old widow, has lived in Cheshire all her life. Neighbors describe Ms. Hern as a feisty, even "cantankerous," person, who was at the forefront of the campaign against AEP. ${ }^{224}$ Thus, her neighbors were surprised at her decision not to sell. ${ }^{225}$ But on closer inspection, this decision may not be surprising at all: It seems that the struggle against AEP gave Ms. Hern a unique personal satisfaction; it clearly got her substantial attention from the media. The campaign against AEP's pollution may have become Ms. Hern's raison d'être. ${ }^{226}$

The other resident owner who decided not to sell spoke to us on condition of anonymity. He grew up in Cheshire as a "Huck Finn on the river."2227 He later left Cheshire, but his lifelong dream was to return to his boyhood home and build a house on the bank of the Ohio River. After retiring, he returned to Cheshire and now lives there with his wife in a mobile home. The buyout put their plan to build a new house on hold. The couple's attitude toward AEP was clearly marked by indignation. The resident owner told us in no uncertain terms: "For a public company to buy a town like that should be illegal." He was upset with AEP for not being a better neighbor and hoped that the Cheshire community would one day be revived, possibly with AEP's help. The couple decided to stay in Cheshire and see how AEP behaves in the future.

The man told us that although the couple is not planning to leave, they do not categorically rule out the option of selling in the future. However, even an offer "three and a half times" as high as the one presented to them will not send them packing. This statement suggests that the couple's initial decision to stay was not strategic. But the thought of selling, if the

\footnotetext{
224. Hammond, supra note 47.

225. Id.

226. In a recent interview, Ms. Hern suggested that she decided not to sell for "sentimental" reasons, noting that "[m]y husband and I had this house built about 1955 and hc's buried-well, I could almost walk to his grave. And I didn't want to move. I'm too old to move to begin with, and I just didn't like the way it was being done. I felt like I wasn't being treated right." Hern Interview, supra note 2 I0. Ms. Hern also stated that "I own more riverfront here than anybody and they offered me $\$ 242,700$ for it . . . . I told their lawyers when they came down here: 'Offer me a million dollars and I'll consider it.' But truthfully I would not even move for that. This is my home." Doran, supra note 209 (emphasis added).
}

227. Anonymous Interview, supra note 206. 
price is right, rests somewhere in the back of their minds. It may have been there all along or it may have developed through time in response to the changed circumstances around them and the actions of their neighbors. Yet the partly ideological and partly strategic motivation makes it impossible to classify them as either pure holdouts or pure holdins. At the end of the day, the two categories are not mutually exclusive; rather, they are at the two extremes of a psychological continuum.

\section{VI}

\section{IMPLiCATIONS FOR COLlECTIVE BARgaining ThEORY}

The events in Cheshire also suggest the need to reexamine the theory of collective action problems as applied to bargaining with groups. The analysis so far has focused on the various acquisition strategies available to polluters in situations involving multiple victims. Yet in Cheshire the residents initiated the buyout; the polluter stepped in at their invitation. ${ }^{228}$ This fact is at odds with the theory of collective action, as illustrated by the following example. Suppose a group of one hundred people could secure a benefit of one hundred thousand dollars if some or all of the group would contribute a total of twenty thousand dollars. Suppose further that the group cannot compel any member to contribute and must rely exclusively on goodwill. Finally, suppose that the benefit of the contributions would flow to all members of the group regardless of their actions. In this situation, as Mancur Olson showed, self-interested individuals will choose not to contribute to the group offer, hoping that others will bear the cost necessary to produce the benefit. ${ }^{229}$ Of course, when everyone behaves in this fashion, the benefit will not be produced, and all group members will be worse off.

The Cheshire buyout deal seemed to share some of the underlying characteristics of this stylized hypothetical. Although some residents stood to gain from selling out to AEP, each had an inherent incentive to maximize her expected payoff by not taking action and letting other interested members bear the cost of securing an offer. A common way to overcome the collective action problem, one that seems to have occurred in Cheshire, is for some group members to assume the role of leaders and spearhead the effort to coordinate the group. ${ }^{230}$ Indeed, certain residents, presumably

228. By "initiated," we do not necessarily mean "made an offer to sell." It is unclear who first came up with the buyout proposal. But it is clear that residents' extensive efforts (lobbying public officials, complaining to AEP, attracting media attention to the town's plight, and intervening in the plant's decisions-for instance, about which abatement technologies to deploy) were instrumental in setting the stage for the buyout.

229. Mancur Olson Jr., The Logic of Collective Action (1965).

230. "The presence of a leader or entrepreneur, who articulates different ways of organizing to improve joint outcomes, is frequently an important initial stimulus [to collective action]." Ostrom, supra note 154 , at 149. 
those who stood to gain the most from selling, led the negotiations with AEP. ${ }^{231}$

The emergence of entrepreneurs, or group leaders, takes care of the collective action problem, but only at the cost of introducing an agency problem. ${ }^{232}$ The fear is, of course, that the entrepreneurs will favor their narrow self-interest over the collective interest of the group. Precisely such allegations arose in Cheshire. ${ }^{233}$ The compensation formula negotiated with AEP was predicated on historic tax assessments, and, consequently, it apparently favored newcomers to the community (or those who had made recent improvements to their property, and thus had it reappraised) over long-term residents whose property had not been on the market for many years. ${ }^{234}$ Coincidentally or not, the residents' representatives who coordinated the buyout were among the relative newcomers to the community. In this sense, reality vindicated the theoretic prediction.

However, the Cheshire case offers a different theoretic novelty. The cooperation between those residents who favored a sale and AEP suggests an alternative solution to the collective action problem in bargaining settings. When coordination costs are asymmetrically distributed between the buyer and the seller, as in the case of a single buyer and multiple sellers, it makes sense for the buyer to shoulder the costs of coordinating the transaction. This principle may be termed the "least cost coordinator."235 In cases like Cheshire, this principle dictates that the polluter should always be the one to initiate the buyout offer. After all, the cost of coordinating a buyout, like all other transaction costs, is a deadweight loss to society, and efficiency requires that such costs be minimized.

The polluter, however, may have strategic reasons not to move first. First among these reasons is the problem of asymmetric information. Although the polluter may be interested in buying, he may not know how much to offer. Recall that the polluter is not just buying the affected

231. Here we refer to Ron Hammond along with Jennifer and Steve Harrison. However, that these residents had more at stake if the deal fell through does not explain why they volunteered to coordinate the deal. They too could increase their personal payoffs by letting others shoulder the cost of coordinating the buyout. In other words, their behavior is inconsistent with the theory of collective action, at least under assumptions of strict rationality.

232. See, e.g., Abraham Rell \& Gideon Parchomovsky, Of Property and Anti-Property: The Perverse Virtues of Transaction Cost and Anticommons (unpublished manuscript, on file with authors).

233. Anonymous Interview, supra note 206.

234. William Fischel pointed out to us that schemes that result in higher taxes for newer residents are called "welcome stranger" assessments in public finance, an ironic term for loading taxes on newcomers. See, e.g., John Vitha, Comment, Allegheny Pittsburgh Coal Co. v. County Commission of Webster County, West Virginia: The Supreme Court Gives "Welcome Stranger" Tax Assessments a Cold Reception, 56 Brook. L. REv. 1383 (1991). Fischel also conveyed that there may be some justice in basing compensation on assessment, since those with the higher assessments had borne more than their fair share of taxes in the past.

235. See generally Guido Calabresi, The Costs of Accidents $135-40$ (1970) (introducing and discussing the cheapest or least cost avoider principle). 
properties, the prices of which are readily accessible, but also immunity from future lawsuits. The residents, on the other hand, have better access to such private information. A second reason the polluter may not move first is to maintain its reputation. Making a buyout offer may signal culpability on the part of the polluter or, at the very least, a fear of legal liability. The informational disadvantage of the polluter exacerbates this concern. For if the polluter's offer is too low and the residents reject it, the polluter's making of the offer by itself might reinforce residents' belief that they have been wronged and prod them to sue. In short, the polluter, unlike the residents, faces a first mover disadvantage. ${ }^{236}$ It is interesting to note that in the context of Cheshire, AEP insisted that a desire to be a good and cooperative neighbor rather than fear of legal liability motivated its behavior. ${ }^{237} \mathrm{~A}$ third reason the polluter may prefer not to initiate a buyout is its hope that the collective action problems affecting victims will prevent them from taking legal action against it. Again, the Cheshire case is illustrative. Although Cheshire residents experienced varying degrees of pollution for several years, to the best of our knowledge only one resident attempted to bring legal action against AEP. That case ultimately settled. ${ }^{238}$

The strategic problems on both sides of a potential buyout may thwart a mutually beneficial bargain between the polIuter and the victims and lock the parties into a stalemate. For the reasons explained, the polluter might be reluctant to initiate an offer to buy, and residents' attempt to coordinate an offer to sell may run aground, or not even take off, because of collective action problems. How can this potential stalemate be avoided? One effective solution is cooperation between some of the residents and the polluter. Specifically, residents who are eager to leave can promote their cause by enlisting the help of the polluter. Instead of incurring the high cost of coordinating their neighbors, any resident can approach the polluter with an offer to sell individually. Although this course of action does not bind other members of the group, it facilitates a collective deal in two ways. First, it provides the polluter with valuable information about the asking price of the residents. Of course, the asking prices of different residents may vary; yet knowing a few asking prices can help the polluter calculate her potential payout and devise a buyout plan acceptable to the residents. It is reasonable to assume that members of close-knit communities share information among themselves about the consideration each of them wishes to get in exchange for departure. Hence, the polluter can infer that the amounts individual members request bear some relationship to the

236. See, e.g., Daniel J. Seidmann \& Alex Stein, The Right to Silence Helps the Innocent: $A$ Game-Theoretic Analysis of the Fifth Amendment Privilege, 114 HARv. L. REv. 430, 447 \& n.56 (2000) (explaining a suspect's first move disadvantage in police interrogations).

237. See, e.g., Teather, supra note 46.

238. Harrison I, supra note 1. 
amounts sought by other community members. Second, individual offers to sell give the polluter an opportunity to portray itself as a "white knight" who charitably comes to the aid of community residents. Seizing on the opportunity to act "gallantly" is likely to help the polluter gain favorable media coverage and thus enhance its reputation.

From the vantage point of residents, the separate action has an obvious downside: it reduces their bargaining power. As is clear from the employment context, collective bargaining leads to better terms, especially in pollution cases, where the polluter is essentially a monopsony. Once a community is hit with pollution, it loses its appeal to potential market buyers, and the only deal residents can potentially secure is to sell to the polluter. In principle, concerted action likely would have secured residents a larger part of the bargaining surplus. However, given the problem of collective action, some members of the residents' group should be expected to choose to deal with the polluter on an individual basis. Indeed, when coordination costs are very high, choosing to do so may be the only viable way to coordinate buyouts.

As just shown, the Cheshire buyout presents several descriptive challenges to conventional economic analysis of the law. Cheshire also suggests some important refinements to takings policy. These refinements are the subject of the following Part.

\section{VII \\ IMPLICATIONS FOR TAKINGS POLICY}

This Article concludes by extending the normative implications of Cheshire to the law and theory of takings. Although Cheshire is a private takings case, it has dramatic implications for the law and policy of eminent domain. Government exercises of eminent domain far outnumber private takings, and accordingly their effect on private property owners and communities is much greater than that of private takings. Furthermore, while private takers should pay above-market compensation to succeed in a buyout offer, the government must pay only fair market value. As a result, government exercises of the eminent domain power erode private property rights much more dramatically than do private takings. Therefore, it is imperative to discuss the lessons of Cheshire for eminent domain theory and practice.

The power of eminent domain is probably the most discussed subject in the whole law of property. The ample writing on the topic is due in part to the fact that it constitutes an important intersection between property and constitutional law, as well as to the vagueness of the Supreme Court's takings jurisprudence. ${ }^{239}$ The scholarly discussion of eminent domain may be

239. As examples, compare Miller v. Schoene, 276 U.S. 272 (1928) (finding no taking where a state regulation required owners to cut down red cedar trees infected with a virus that could kill apple 
divided into three broad categories. The first category focuses on the question of how one should classify takings. ${ }^{240}$ The second addresses the constitutional question of which government acts require compensation. ${ }^{241}$ The third is concerned with the question of what "just compensation" means. ${ }^{242}$ The evidence of community externalities in the Cheshire buyout offers important contributions to the first and third categories of takings scholarship.

\section{A. A New Takings Taxonomy}

At present, the only accepted method of classifying takings is functional, based on their effect on property. The Supreme Court has

trees) with Department of Agriculture \& Consumer Services v. Mid-Florida Growers, Inc, 521 So. $2 \mathrm{~d}$ 101 (Fla. 1988) (holding full and just compensation required when state, pursuant to its police power, destroyed healthy trees), cert. denied, 488 U.S. 870 (1988). Additionally, compare Pennsylvania Coal Co. v. Mahon, 260 U.S. 393 (1922) (holding that elimination of mining rights is a taking) with Keystone Bituminous Coal Ass'n v. DeBenedictis, 480 U.S. 470 (1987) (holding that elimination of mining rights is not a taking). For academic analysis of Supreme Court jurisprudence in this area, see Bruce A. Ackerman, Private Property and the Constitution 3 (1977) (suggesting that takings jurisprudence is a "set of confused judicial responses"); Raymond R. Coletta, Reciprocity of Advantage and Regulatory Takings: Toward a New Theory of Takings Jurisprudence, 40 AM. U. L. REV. 297, 299-300 (1990) (characterizing takings jurisprudence as a "chameleon of ad hoc decisions that has bred considerable confusion"); Gideon Kanner, Hunting the Snark, Not the Quark: Has the Supreme Court Been Competent in Its Effort to Formulate Coherent Regulatory Takings Law?, 30 URB. LAw. 307, 308 (1998) ("The incoherence of the U.S. Supreme Court's output in this field has by now been demonstrated time and again by practitioners and academic commentators ad nauseam, and I refuse to add to the ongoing gratuitous slaughter of trees for the paper consumed in this frustrating and inherently pointless enterprise."); Andrea L. Peterson, The Takings Clause: In Search of Underlying Principles, Part I-A Critique of Current Takings Clause Doctrine, 77 CALIF. L. Rev. 1301, 1304 (1989) ("[I]t is difficult to imagine a body of case law in greater doctrinal and conceptual disarray."); Carol M. Rose, Mahon Reconstructed: Why the Takings Issue Is Still a Muddle, 57 S. CAL. L. REV. 561 (1984).

240. See, e.g., Bell \& Parchomovsky, supra note 26, at 280-81 (discussing different types of takings); Abraham Bell \& Gideon Parchomovsky, Givings, 111 YALE L.J. 547 (2001) [hereinafter Bell \& Parchomovsky, Givings] (providing a taxonomy of givings).

241. See, e.g., Richard A. Epstein, Takings: Private Property and the Power of Eminent DOMAIN (1985) (arguing that any govemment action that diminishes property values should be considered a taking for which compensation is constitutionally mandated); WILLIAM A. FISCHEL, Regulatory TAKINGS: LAW, ECONOMICS AND Politics 351-53 (1995) (arguing that compensable takings should be found where regulations diverge from social norms); Frank 1. Michelman, Property, Utility, and Fairness: Comments on the Ethical Foundations of "Just Compensation" Law, 80 Harv. L. REV. 1165, 1215 (1967) (proposing that compensation for regulatory takings be paid when demoralization costs exceed settlement costs); Joseph L. Sax, Takings and the Police Power, 74 Y ALE L.J. 36, 62-63 (1964) (requiring compensation whenever the government acts like an enterprise, such as when it uses the property to provide goods or services, but not when it arbitrates private disputes-for instance, by preventing noxious uses).

242. See, e.g., Abraham Bell, Not Just Compensation, 13 J. Contemp. Legal Issues 29 (2003) (arguing for downward adjustment of compensation awards to combat moral hazard); Hanoch Dagan, Takings and Distributive Justice, 85 VA. L. REv. 741 (1999) (advocating a progressive compensation system that would award greater compensation to poor condemnees relative to affluent ones). 
recognized two prototypes of takings, physical and regulatory. ${ }^{243}$ However, academic commentators have observed a third prototype, derivative takings. ${ }^{244}$ ln mapping the terrain of takings, Bell and Parchomovsky explained the three prototypes as follows:

A physical taking occurs when the state seizes a property interest in order to put it to public use. In a regulatory taking, the state does not seize the property interest, but regulates its use in a manner that unduly diminishes property values. A derivative taking is present whenever a taking diminishes the value of surrounding property. Derivative takings are a hybrid of their more familiar close cousins. They resemble regulatory takings in that they reduce the value of property without physically appropriating it. Yet, they are distinct from regulatory takings in that they may arise as the result of a physical taking. And, unlike its cousins, the derivative taking never appears alone; it must always be preceded by a physical or a regulatory taking. ${ }^{245}$

Although the existing typology of takings helps illuminate which kinds of government actions may give rise to a duty to compensate, it fails to take account of the number of properties affected by government action. Notwithstanding scholarly acknowledgment of the ripple effects of traditional takings, ${ }^{246}$ and Bell and Parchomovsky's concept of derivative takings, ${ }^{247}$ the judicial prism remains restricted to property directly targeted by government actions. Adjacent property that is indirectly affected and whose owners stand to suffer considerable diminution in value fall outside the purview of the Takings Clause of the Fifth Amendment. ${ }^{248}$ Use, not value, is the sine qua non of compensation, so without government restriction on the owner's use of the property, loss of value, no matter how great, will not give rise to compensation. Furthermore, in the case of property owners who qualify for compensation under this restrictive test, the Supreme Court has interpreted the constitutional requirement of just compensation to mean payment of fair market value. ${ }^{249}$ Although academic

243. Pennsylvania Coal Co. v. Mahon, 260 U.S. 393 (1922) (recognizing the possibility that regulation may constitute a taking under the Fifth Amendment). For a historic review of the Takings Clause, see William Michael Treanor, The Original Understanding of the Takings Clause and the Political Process, 95 CoLum. L. Rev. 782 (1995).

244. Bell \& Parchomovsky, supra note 26 , at 280.

245. Id. at 280-8 I (footnotes omitted).

246. See generally WINDFAlls fOR WiPEOUTS: LAND VAlUe CAPTURE AND COMPENSATION (Donald G. Hagman \& Dean J. Misczynski eds., 1978).

247. Bell \& Parchomovsky, supra note 26.

248. See, e.g., United States v. Causby, 328 U.S. 256 (1946) (holding that only those property owners whose houses lay directly below the air routes had a right to compensation under the Fifth Amendment).

249. See, e.g., Kimball Laundry Co. v. United States, 338 U.S. 1, 5 (1949) ("[L]oss to the owner of nontransferable values deriving from his unique need for property or idiosyncratic attachment to it, likc loss due to an exercise of the police power, is properly treated as part of the burden of common 
commentators have proposed other compensation measures based on various criteria, ${ }^{250}$ they too have failed to acknowledge the important implications to takings doctrine of the number of properties affected by the government action.

The incompleteness of current theory and doctrine is likely to lead to harsh consequences for property owners in many small places characterized by community externalities. Consider the following example. Suppose that to pave a new interstate highway, the government must condemn $40 \%$ of the properties in Amityville, a small, three-hundred-person community. As is the case in many small places, Amityville is characterized by strong interpersonal ties. Furthermore, for the local amenities to be sustained, all current properties must remain residential. The interpersonal ties, although strong, are not fully captured by the market value of the properties. How will the execution of the highway plan affect Amityville? The owners of the condemned properties will receive compensation in the amount of the market value of their properties. In all likelihood, this measure will fall short of the subjective value the condemnees assigned to their properties, because it would exclude the value component property owners place on their community. Despite this undercompensation, such residents would nevertheless fare better than their neighbors whose properties the government chose not to take. Those Ieft behind will find themselves in an unsustainable community, bereft of valuable personal friendships, and living near a new interstate highway that is likely to further devalue their properties. And they will receive no compensation whatsoever. ${ }^{251}$

The gross undercompensation suffered by the residents of Amityville is disconcerting on both fairness and efficiency grounds. The outcome is unfair because it violates the principle enunciated by the Supreme Court in Armstrong $v$. United States that it is wrong to "forc[e] some people alone to bear public burdens which, in all fairness and justice, should be borne by the public as a whole." 252 The outcome is also inefficient because it enables the government to externalize a substantial part of the cost of its policies on private property owners, thereby leading to inaccurate assessments of the cost-effectiveness and desirability of government policies. In close cases,

citizenship."); United States v. Miller, 317 U.S. 369, 374 (1943) (explaining that, for practical reasons, "courts early adopted, and have retained, the concept of fair market value" in determining takings compensation); Olson v. United States, 292 U.S. 246, 255 (1934) (stating that just compensation "does not cxceed market value fairly determined").

250. See, e.g., Laura H. Burney, Just Compensation and the Condemnation of Future Interests: Empirical Evidence of the Failure of Market Value, 1989 BYU L. REv. 789, 791 (demonstrating "the general inappropriateness of strictly adhering to any one predetermined standard [of compensation]"); Dagan, supra note 242.

251. Of course, government condemnations and regulations may also increase the value of surrounding property. For a discussion of this possibility and the appropriate legal response, see Bell \& Parchomovsky, Givings, supra note 240 (developing a givings jurisprudence).

252. 364 U.S. $40,49(1960)$ 
the undercompensation may result in inefficient exercises of the eminent domain power.

To design a fairer and more efficient takings rcgime for cases involving community externalities, it is necessary to introduce a quantitative dimension to the existing conceptual framework for analyzing takings. When community externalities exist, the main focus of the judicial inquiry should not be so much the characterization of the government action as a physical, regulatory, or derivative taking, but rather the effect of the action on the relevant community. ${ }^{253}$ To accomplish this task, courts should separate the universe of takings cases into three novel conceptual categories: isolated takings, tippings, and clearings.

The first category, isolated takings, consists of discrete exercises of eminent domain power. A typical example of a case in this category is the condemnation of a single parcel to be used for a school. Instances of isolated takings are relatively rare, however. Typically, government actions in the area of land use control involve a large number of parcels and, correspondingly, a large number of owners. As a rule, isolated takings will not undermine community externalities, and thus should have little or no impact on the community at large. Even so, the owner of the taken property is likely to be undercompensated by an award of fair market value because it would not compensate him for the loss of valuable interpersonal ties. ${ }^{254}$

The second category, tippings, is more common and thus presents a far greater challenge. ${ }^{255}$ This category encompasses all cases in which the government condemns multiple properties in a community, potentially making unsustainable the provision of community amenities and disrupting community life. By analogy to Schelling's model of racial segregation, the forced exit of a sufficiently large subset of property owners can cause the destruction of the entire community. Tippings therefore affect both those whose property was taken and those whose legal interest in their property was not affected. The current compensation regime adequately compensates neither group. The payment of fair market value to owners in the first category does not compensate them for the lost value of the community. The remaining owners, whose legal interest was not taken, will receive no compensation at all.

253. The analysis here focuses on taking of a fee simple interest to the entire property. Of course, the government may also exercise its power to take a lesser interest, such as a servitude, or to appropriate a part of the property. In such cases, the effect on the community should be less drastic, and one would expect the community to remain vital and functional. However, there should be no hard and fast rules, and in each case courts should carefully examine the potential effect of the government action on the community.

254. It is possible, however, that the condemnee could use the compensation award to purchase a substitute home in the same community. This option is available to the condemnee precisely because the community externality is not fully reflected in property prices.

255. See supra note 192. 
The third category, clearings, covers instances in which communities are uprooted in their entirety. In these rare cases, the default rule should be compensation in kind-that is, provision of a substitute location for resettlement. This solution would allow for preservation of community character, albeit in a different place. Of course, this measure should not be coercive, and uninterested property owners should be able to opt out and collect monetary damages.

The best-known case of a clearing is Poletown Neighborhood Council $v$. City of Detroit. ${ }^{256}$ There, the city government exercised its eminent domain power to condemn all the properties in the Poletown neighborhood to allow General Motors to build a new automobile-manufacturing facility. On the whole, the city of Detroit condemned 1,400 homes, 144 businesses, and 16 churches, many of which were turned into landscaped lawns, ponds, and parking lots surrounding the General Motors plant. ${ }^{257}$ Jeanie Wylie's poignant, firsthand account of the condemnation process amply demonstrates the devastating effects of the clearing on the residents of Poletown. ${ }^{258}$ Wylie reported that in the aftermath of the taking, many residents were unable to resume their normal lives. ${ }^{259}$ The community served as their compass for daily life, and after its destruction they lost their sense of direction. ${ }^{260}$

The story of Poletown is by no means an isolated one. Urban renewaI and redevelopment plans often replicate the outcome in Poletown. For example, between 1946 and 1953, the urban renewal projects executed in New York under the supervision of Robert Moses "changed the face of whole neighborhoods." 261 According to City Planning Commission estimates, these projects led to the uprooting of more than 250,000 people and the condemnation of hundreds of apartment buildings, stores, and factories. ${ }^{262}$ Many other American cities carried out similar renewal projects

\footnotetext{
256. 304 N.W.2d 455 (Mich. 1981).

257. See Jeanie Wylie, Poletown: Community Betrayed $51-52$ (1989).

258. Id.

259. Id.

260. According to Wylie, several residents died shortly after they had been forced to leave Poletown. Id. at 194-98. She also suggested that the priest of the lmmaculate Conception Church that served the Polctown community "died of a broken heart." Id. at 198. Herbert J. Gans reported that the redevelopment of Boston's West End had a similar effect on local residents. See Herbert J. Gans, The Urban Villagers: Group and Class in the Life of Italian-Americans 320 (1962) ("For tenants, owners, and businessmen alike, the destruction of the neighborhood exacted social and psychological losses. The clearance destroyed not only buildings, but also a functioning social system. The scattering of family units and friends was especially harmful to the many older people.").

261. Wendell E. Pritchett, The "Public Menace" of Blight: Urban Renewal and the Private Uses of Eminent Domain, 21 Yale L. \& POL'y Rev. 1, 37 (2003).

262. Id. (citing Robert A. Caro, The Power Broker: Robert Moses and the fall of New YORK 965-68(1974)).
} 
during that period. ${ }^{263}$ In many of those cases, property owners likely suffered severe losses for which the government did not adequately compensate them. ${ }^{264}$

\section{B. Just Compensation}

To take account of the full effect of eminent domain exercises on small communities, courts ought to do two things. First, courts ought to broaden the focus of the compensation inquiry beyond the lots directly affected. Second, they should recognize that property owners stand to suffer a loss well in excess of fair market value as a result of government takings, and should compensate them at a premium. ${ }^{265}$ At first blush, compensation at a premium may seem like a radical idea. It is not. Compensation at a premium used to be the rule in the United Kingdom ${ }^{266}$ and still is the rule in

263. See Berman v. Parker, 348 U.S. 26, $34-35$ (1954) (finding constitutional the urban redevelopment plan of southwest Washington); Wendell Pritchett, Brownsville, Brooklyn 24350 (2002) (discussing how urban renewal led to the destruction of Brownsville, Brooklyn); JoN C. Teaford, The Rough Road to Renaissance 154-62 (1990) (describing the effects of various urban renewal projects on local communities); cf. Brion, supra note 177, at $687-702$ (1991) (discussing the Redevelopment Act's harsh effects on individual residents in southwest Washington). For a historic review of urban development plans in the United States, see Pritchett, supra note 261, at 31-47.

264. See, e.g., Michael A. Heller, The Boundaries of Private Property, 108 YALE L.J. 1163,1221 n.284 (1999) (observing that "[t]here was a substantial question whether the switch to factory use [in Poletown] improved overall utility because the fair market value system of compensation misses the subjective and community values destroyed by bundling").

Urban renewal and redevelopment present an interesting challenge for this proposal since they sometimes (depending on their scope) fall into the category of tippings. Although by tipping communities out such measures no doubt devastate communities and neighborhoods, in the long run thcy may positively affect the property values of community members who remain. Thus, the compensation award to residents whose property was not condemned should be adjusted to reflect this fact. Yet the increase in property values does not happen overnight; nor is it a certain outcome. It often takes years to complete renewal plans, and the expected increase may not materialize. The case of Levine v. City of New Haven, 294 A.2d 644 (Conn. Super. Ct. 1972), is illustrative. There, the plaintiff brought an inverse condemnation suit after New Haven included his property in a redevelopment area but did not take it for nine years. As a result, "plaintiff's property suffered from the normal consequences of the planning of a redevclopment area in that the gencral area suffered depreciation in value, vandalism and loss of tenants, among other deteriorating factors." Id. at 645 .

265. Neither of these changes necessarily requires legislative intervention but rather a change in the judicial approach. Nothing in the language of the Constitution dictates that takings compensation is available only to owners of directly affected property. In fact, in Pennsylvania Coal Co. v. Mahon, 260 U.S. 393 (1922), the first case to recognize the possibility of a regulatory taking, the Court predicated its decision on the principle of undue diminution in value. If undue diminution in value is the touchstone of compensation, there is no logical reason to limit its application to only certain lots. Likewise, the Takings Clause does not mention fair market value as the right compensation measure. The courts adopted this measure primarily for practical reasons. See United States v. 564.54 Acres of Land, 441 U.S. 506, 511 (1979) ("Becausc of serious practical difficulties in assessing the worth an individual places on particular property at a given time, we have recognized the need for a relatively objective working rule."). Below, we show that fear of difficult assessmcnt problems does not necessarily apply to community value, and we suggest how compensation for loss of community may be administered at a relatively low cost. See infra text accompanying note 276.

266. DUKEMINIER \& KRIER, supra note 129, at 1115 n.14. In the United States, Ellickson proposed award of bonuses to compensate for subjective loss. See Robert C. Ellickson, Alternatives to 
Canada. ${ }^{267}$ In both cases the increased award was intended to soften the negative impact of the taking, irrespective of any community effects. ${ }^{268}$ Congress also authorized a premium in the New Hampshire Mill Act at issue in the late-nineteenth-century case of Head v. Amoskeag Manufacturing Co. ${ }^{269}$

Implementation of the proposed compensation regime should proceed based on the distinction among isolated takings, tippings, and clearings. Because isolated takings do not affect the fabric of the community, the compensation inquiry should focus exclusively on the individual condemnee or condemnees. In this case, courts should consider compensating the condemnee at a premium to reflect the special harm she has suffered. ${ }^{270}$ However, courts should not automatically award heightened compensation; instead, they should look at the availability of substitute property in the relevant community. When similar property is available, an award of fair market value should suffice because the condemnee can use the compensation award to purchase a new home in the same community.

In cases of tippings, the focus of the inquiry should be expanded to cover property owners not directly affected by the government action. Compensation should not be limited to owners whose property was taken; rather, it should extend to the remaining owners as well. The actual amount paid should vary, though. Owners whose property was condemned should be entitled to fair market value and a community premium. The remaining owners whose property was not condemned should receive the community premium but not fair market value. ${ }^{27 !}$

Finally, in cases of clearings, which affect all members of the relevant community, a system of compensation in kind is appropriate. To avoid the difficulty of accurately estimating the community premium, the government might offer all community members a substitute site where the

Zoning: Covenants, Nuisance Rules, and Fines as Land Use Controls, 40 U. CHI. L. Rev. 681, 736-37 (1973).

267. See DUKEMINIER \& KRIER, supra note 129 , at 1115 n.14.

268. Id.

269. 113 U.S. 9 (1885). The challenged statute required compensation-at a $50 \%$ premium over fair market value-for owners of property flooded by the damming of rivers necessary to operate mills.

270. See Brion, supra note 177, at 734 ("Incorporating the consideration of communality into the compensation issue would require an accounting of the value that the community brought to the expropriated owners.").

271. We are aware that, insofar as the loss of community is concerned, the harm suffered by the condemnees is not identical to that of the remaining community members. The latter group may have incurred a greater or lesser loss depending on how the government is going to use the newly "acquired" property. For instance, the construction of a highway may further reduce the property values of the remaining owners. Yet, for simplicity's sake, we advocate a uniform compensation premium as a default rule. In appropriate cases, courts should have the discretion to differcntiate the premium paid to various property owners, although this discretion naturally creates significant administrative burdens on the judiciary. 
community could resettle and start afresh. ${ }^{272}$ Indeed, the government used a similar remedy in Valmeyer, Illinois. After floods repeatedly damagcd the town, the government provided substantial funds to relocate the entire town to higher ground a mile from its previous site. ${ }^{273}$

Of course, community members should not be forced to relocate to a certain site-such coercion would undermine the goal of the project. Members who prefer to continue their lives elsewhere should be allowed to collect damages and go thcir separate ways. The damage award in such cases should be fair market value plus a community premium. We summarize the proposed compensation regime in Table 3.

TABLE 3

Current and Proposed Rules for Takings Compensation

\begin{tabular}{|c|l|l|l|}
\hline \multirow{2}{*}{$\begin{array}{l}\text { Type of } \\
\text { Taking }\end{array}$} & \multicolumn{1}{|c|}{$\begin{array}{c}\text { Current } \\
\text { Compensation }\end{array}$} & \multicolumn{1}{c|}{ Proposed Remedy } \\
\cline { 3 - 4 } Isolated & $\begin{array}{l}\text { Fair Market Value } \\
\text { (FMV) }\end{array}$ & $\begin{array}{l}\text { FMV plus premium to } \\
\text { compensate for loss of } \\
\text { community }\end{array}$ & $\begin{array}{l}\text { No } \\
\text { compensation }\end{array}$ \\
\hline Tipping & $\begin{array}{l}\text { FMV for condemnee; } \\
\text { 0 for all others }\end{array}$ & FMV plus premium & Premium only \\
\hline Clearing & FMV for all owners & $\begin{array}{l}\text { Resettlement of entire } \\
\text { community, with op- } \\
\text { tion of compensation } \\
\text { at FMV plus premium }\end{array}$ & $\begin{array}{l}\text { N/A (all owners } \\
\text { affected) }\end{array}$ \\
\hline
\end{tabular}

The proposed compensation regime is by no means limited to small communities in rural areas. The same principles should be extended to cohesive communities in larger urban areas. However, not every compensation scheme should necessarily incorporate a community premium. One important factor courts should consider in determining eligibility is the

272. For discussion of compensation in kind, see Lee Anne Fennell, Hard Bargains and Real Steals: Land Use Exactions Revisited, 86 Iowa L. Rev. 1 (2000).

273. Sadly, although many residents did move, much of the community spirit seems to have been lost in the process.

Some Old Valmeyer residents moved to the new subdivision, but many left the area entirely. Younger families from elsewhere, attracted by the school, have moved in, but they shop and play somewhere else. About 600 people live there.

In the mcantime, the businesses that remained in Old Valmeyer have shut down or moved. The community's cohesion, and any sense of a place with a history, went out with the flood. "I hardly know anybody going down the road," said Bernice Meadors, who moved her tavern, the Corner Pub, from the old town to the new town after the flood. "l thought the people would come back. But those people who livc up here, they don't come from here. The heart is gone."

Kilborn, supra note 174 , at A15. 
turnover rate in the community. ${ }^{274}$ Another factor to consider is the existence of community amenities.

One might oppose this proposal on grounds of administrability. As courts and commentators have noted, fair market value is relatively easy to determine, and any deviation from that standard might not be cost effective. ${ }^{275}$ Administrability concerns, although often valid, are not warranted in this case. Adding a set compensation premium should not affect in the least the cost of determining compensation. Insofar as administrability is concerned, there is no difference between awarding fair market value and $120 \%$ of that amount. In appropriate cases, courts should have discretion to adjust the community premium. But even so, administrative costs should remain manageable as long as courts award the same premium to all affected property owners.

A related objection is that the value of the community, very much like idiosyncratic value, is unascertainable and should therefore remain noncompensable. This objection has some merit, but it cannot carry the day. That a loss may not be precisely ascertained does not require a nocompensation rule. In tort law, for example, the modern trend is to award compensation for emotional harms that accompany physical injuries, despite the fact that emotional harm is idiosyncratic and unascertainable. ${ }^{276}$ The community losses accompanying property takings seem analogous to emotional harm in all relevant respects. Furthermore, community losses, unlike purely idiosyncratic ones, are relatively ascertainable. Objective indicia such as turnover rate and presence of community amenities can aid courts in determining eligibility for a community premium. Admittedly, it will be impossible to compensate each property owner for his precise subjective loss. But even imprecise compensation along the lines we propose will advance both fairness and efficiency, relative to the current nocompensation regime.

\section{CONCLUSION}

That reality is complicated should hardly come as news to any scholar. But the story of Cheshire reveals how truly complex the analysis of real-world pollution disputes can be. It is a story of crosscutting

274. An important legal determinant affecting tumover rates in large metropolitan cities is rent control. Indeed, Peggy Radin justified rent control schemes on the grounds that they allow strong interpersonal ties to develop. Margaret Jane Radin, Market-Inalienability, 100 HaRv. L. REv. 1849, 1878 (1987) (arguing that economic analysis should take into "account not only the monetary costs to landlords and would-be tenants, but also the decline in well-being of tenants who are forced to lose their homes, [and] break up their communities").

275. See, e.g., United States v. Miller, 317 U.S. 369, 374 (1943); David A. Dana \& Thomas W. Merrill, Property: TAKINGS 175 (2002) (explaining why fair market value is the accepted compensation standard).

276. See John C.P. Goldberg \& Benjamin C. Zipursky, Unrealized Torts, 88 VA. L. REv. 1625, $1674 \&$ n.135 (2002) (summarizing the law with respect to emotional harm). 
motivations, unresolvable factual questions, and difficult judgments. Take a facially simple question: Did the residents of Cheshire get a good deal when they sold to AEP? Resolving this question is of course key to any analysis of the economic efficiency of buyouts as a solution to pollution disputes. At first glance, the answer appears to be a pretty clear yes, at least for most people. After all, sellers received a multiple of their properties' assessed valuations, which seems fairly generous. The correct answer, if there is one, is much more nuanced, however, for several reasons.

First, it is not clear what constitutes the proper baseline against which valuations should be measured. No viable market for properties existed in Cheshire for at least the three years before the buyout because of the pollution problem. Hence, although residents may have preferred selling to AEP over staying and living with pollution, it is not clear whether they would have preferred selling to staying without pollution. That option was never really on the table.

Second, this was not a simple land transaction: as part of the deal, residents had to waive their rights to any future health claims against AEP. What was being sold was a mixture of real property plus liability claims of uncertain value. Although no evidence currently suggests that the pollution in Cheshire has had cumulative or long-term health effects on residents, the precise nature of these effects is still anyone's guess. Perhaps in five years residents will come to regret signing away their future health claims. The cognitive imperfections and psychological difficulties people face in making calculations about risks (especially regarding latent hazards) have been well documented ${ }^{277}$ Hence, it might well be inappropriate to assume that residents of Cheshire simply made unbiased predictions of the future costs and benefits of the deal and took the course of action with the largest expected utility. In other words, even those who express satisfaction with the deal may be basing their approval on an optimistic undervaluation of the health claims they signed away.

Third, some people in Cheshire were apparently reluctant sellers who would have preferred to stay if there had been enough others who were also willing to do so. At least some residents feared that, if they decided to remain, they would have been left in a ghost town, with no neighbors other than a mountainous heap of coal, and with property no one would ever buy. As argued earlier, community externalities in Cheshire suggest a mechanism by which some residents might have been coerced into selling. One might raise further questions about the distribution of gains from the sales; it is possible that residents who purchased land more recently, and hence had newer and higher tax assessments, received a better deal than others who had held their land for a longer period.

277. For a summary and analysis of this evidence in a lcgal setting, see Christine Jolls et al., $A$ Behavioral Approach to Law and Economics, 50 STAN. L. Rev. 1471 (1998). 
Finally, there is a question of the value of the community itself. Even before the pollution problems began, Cheshire was certainly not a conflict-free Utopia. ${ }^{278}$ Neither, undoubtedly, were Valmeyer, Illinois, or the Poletown neighborhood in Detroit, or the Chicago neighborhoods of the 1950 s depicted by Ehrenhalt. ${ }^{279}$ Communities can be stifling and can breed narrow-mindedness and conformity. ${ }^{280}$ Moreover, they can support the wrong kinds of values, as in the segregated communities of the Jim Crow South.

Nevertheless, what happened in Cheshire suggests that it would be wrong to dismiss communities as nothing more than temporary assemblies of atomistic individuals, places with no significance other than as geographic boundaries on a map. Intangible and fragile as it may be, a sense of community is obviously something of great importance to many residents of small towns and urban neighborhoods. Precisely this sense of community was destroyed in the Cheshire buyout. Whether or not AEP paid "adequate compensation," it is nevertheless critical to take account of the importance of what has been lost.

Consider the fact that the Cheshire buyout attracted attention from newspapers in New York, Chicago, Los Angeles, and Baltimore. Fox Television interviewed Cheshire's residents, and ABC News documented the village's pollution problems. ${ }^{281}$ Reporters from France, Germany, and England visited the town. What about the buyout made it such a compelling story? We are quite convinced that the press and public did not see the story of Cheshire as the triumph of the Coase Theorem, in which the right to pollute was allocated to the party who valued it most (in this case, the polluter). Instead, we attribute the public's fascination to the story's underlying message about the fragility of communities in the face of market forces. As such, what happened in Cheshire embodied the downside of the movement from "status to contract" that Sir Henry Maine declared to be the hallmark of modernity. ${ }^{282}$ It is ineumbent on law and economics scholars to take note of this phenomenon; one cannot begin to do so with models

278. For example, the Craycraft family, which owned a number of lots in Cheshire, had disputes with neighbors over rundown property and the criminal activity of some of their children. They also allegedly reccived "telephone calls, things sent in the mail, threats," according to one family member. "The N-word flew. Callers would say to get out of town or we'd be shot," allegedly because the wife of the family's oldest son, Nick, is Black. Rita Price, A Golden Opportunity, Columbus DisP., July 28, 2002 , at $\mathrm{Cl}$. Although reprchensible, this racial animus can be interpreted as evidence of hostility to outsiders-and an attendant sense of internal coherence--that is often attributed to small rural communities.

279. EHRENHALT, supra note 17.

280. See, e.g., Sherwood ANDERSON, Winesburg, Ohio (1919).

281. On the Record, supra note 167; ABC Nightly News, supra note 167.

282. Henry Sumner Maine, ancient law: Its Connection with the Early History of SOCIETY, AND lTS RELATION TO MODERN IDEAS, 164-65 (1864) ("[T]he movement of the progressive societies has hitherto been a movement from Status to Contract."). 
or theories that do not recognize the existence of communities and the vital roles they play. ${ }^{283}$

\author{
APPENDiX: One YeAR LATER \\ The Columbus Dispatch (Ohio) \\ July 22, 2003 Tuesday, Home Final Edition ${ }^{284}$
}

\title{
Cheshire Like 'Ghost Town' for Residents Who Stayed \\ By Mary Beth Lane
}

CHESHIRE, OHIO These days, Helen Preston steers her motorized cart through streets that don't lead to much of anywhere.

"I got this cart to visit my neighbors, and I don't have any now," said the 89-year-old village resident. "I can go on this cart and never talk to a person.

"It's a ghost town."

Already reduced to windowless, doorless skeletons skinned of siding and decor, the houses that greet Preston's gaze now are boarded and sport "no trespassing" signs.

They await demolition, as American Electric Power completes its buyout of this Ohio River village.

The real-estate closings are virtually done, and most of the 221 occupants have moved.

On the way out - and with AEP's permission - many villagers have picked their houses clean of siding, roofing and woodwork. They have pulled pipes, windows and doors from their moorings and sold them for salvage.

Preston, a widow, is among a handful of older residents who took the buyout but were allowed to stay, rent-free, as long as they like.

She still lives in her childhood home along Rt. 7, which is what she wanted.

But with the once-tidy town now looking so tattered, others who stayed behind look forward to the imminent demolitions.

This is the intermediate time.

A local AEP representative told the Village Council this month that the company plans to raze the houses, fill and cap the septic systems, spread topsoil and plant grass.

283. Economists have begun to pay attention to the importance of nonmarket forces such as communities. For a few examples of recent theoretical and empirical discussions, see Samuel Bowles \& Herbert Gintis, Social Capital and Community Governance, 112 EcoN. J. 412 (2002); Edward Glaeser et al., An Economic Approach to Social Capital, 112 ECoN. J. 437 (2002); and Glaeser, supra note 170. This literature has not yet made its way into law and economics, however.

284. Mary Beth Lane, Cheshire Like 'Ghost Town' for Residents Who Stayed, Columbus Disp., July 22, 2003. Copyright (C) 2003 The Columbus Dispatch. Reprinted with permission of the publisher. 
"If the houses are torn down and they keep it looking nice, it would be nicer than what we have now," said 81-year-old Gladys Rife, who took the buyout but is remaining in her home. "I' $m$ here till I die."

Company officials have said they wanted the properties to allow more space to unload coal-carrying river barges serving the Gen. James M. Gavin electric plant.

Spokeswoman Melissa McHenry said last week, however, that future use of the land is uncertain.

Most of the residential property has changed hands. Now AEP plans to purchase the local Methodist church and a small commercial building, both along Rt. 7 .

As the village continues to empty, some who have started new lives elsewhere are glad they moved.

"I love it. 1t's just wonderful," said Mary Phoenix, who with her husband and eight children, has resettled on 6 acres in Bidwell, 10 miles west. But when she looks back, she also misses Cheshire: "I miss the people. The old folks, 1 love them to death."

Left behind as well are neighbors outside Cheshire, who weren't included in the buyout offer and continue to chafe at what they say is AEP's failure to clean up emissions.

The deal that emerged in April 2002 offered villagers as much as $31 / 2$ times the worth of their properties if they signed an agreement not to sue over any health problems claimed in connection with smokestack emissions from the plant.

Citizens Against Pollution, a group of residents from just outside the village limits, still meets.

"Since they bought out Cheshire, I feel like they just don't care, and it's getting worse," said Stephanie Mulford, a member of the group.

She said that a cloud of eye-stinging emissions, known locally as the blue plume, swept down from the smokestacks twice recently.

"My eyes were burning really bad. They hurt," she said.

Officials at the Gavin plant were unaware of any problems, McHenry said.

Last week, Preston watched from the seat in her cart as movers delicately lifted a house from its foundation and prepared to carry it 10 miles inland. Several homeowners have sold their dwellings to others, who are moving them.

Her face was pensive beneath her sun visor.

"You know, it seems like a dream. Sometimes I think I'll wake up and the town would still be here." 